\title{
The Public Housing Referendum Case, Zoning, and the Supreme Court ${ }^{\dagger}$
}

\author{
George Lefcoe*
}

\author{
INTRODUCTION \\ A. The Apparent Message of James v. Valtierra
}

Before a low-rent public housing project may be constructed anywhere in California, article XXXIV of the California constitution requires that it be approved by the community. ${ }^{1}$ No similar requirement

$\dagger$ Bruce Ackerman prepared many of the footnotes for this paper and contributed substantially to the discussion of the recent Supreme Court decisions. Mr. Ackerman is a research associate on HUD contract H-1260 at the Umiversity of Southern California.

* Professor of Law, University of Southern California Law Center. A.B. 1959, Dartmouth College; LL.B. 1962, Yale University. Consultant to Richard C. Van Dusen, Under Secretary, United States Department of Housing and Urban Development. The views expressed in this article are the author's and not those of HUD or of the University of Southern California.

1. CAL. Const. art. XXXIV:

Article XXXIV PUBLIC HOUSING PROJECT LAW. 1. Approval of electors; definitions. Section 1. No low rent housing project shall hereafter be developed, constructed, or acquired in any manner by any state public body until, a majority of the qualified electors of the city, town or county, as the case may be, in which it is proposed to develop, construct, or acquire the sane, voting upon such issue, approve such project by voting in favor thereof at an election to be held for that purpose, or at any general or special election.

For the purposes of this article the term "low rent housing project" shall mean any development composed of urban or rural dwellings, apartments or other living accommodations for persons of low income, financed im whole or in part by the Federal Government or a state public body or to which the Federal Governinent or a state public body extends assistance by supplying all or part of the labor, by guaranteeing the payment of hens, or otherwise. For the purpose of this article only there shall be excluded from the term "low rent housing project" any such project where there shall be in existence on the effective date hereof, a contract for financial assistance between any state public body and the Federal Government in respect to such project.

For the purposes of this article only "persons of low income" shall mean persons or families who lack the amount of income which is necessary (as determined by the state public body developing, constructing, or acquiring the housing project) to enable them, without financial assistance, to live in decent, safe and sanitary dwellings, without overcrowding.

For the purposes of this article the term "state public body" shall mean this State, or any city, city and county, county, district, authority, agency, or any other subdivision or public body of this State.

For the purposes of this article the term "Federal Government" shall mean the United States of America, or any agency or instrumentality, corporate or otherwise, of the United States of America. 
is imposed on those forms of federal assistance, such as FHA mortgage insurance or urban renewal, that tend to benefit middle- and upperincome people. ${ }^{2}$ Recently article XXXIV was challenged as denying to poor people, and therefore inferentially to racial minorities, the equal protection of the laws. A three-judge federal district court sustained the challenge, starting with the premise that the congruence of race with poverty was sufficient to justify treating classifications based on wealth or poverty as if they had been based on race alone, hence "constitutionally suspect" and subject to "a far heavier burden of justification than other classifications." 3 The court said:

Although Article XXXIV does not specifically require a referendum for low income projects which will be predominantly occupied by Negroes or other minority groups, the equal protection clause is violated if a "special burden" is placed on those groups by operation of the challenged provision, if the reality is that the law's impact falls on the minority. ${ }^{4}$

On April 26, 1971, the United States Supreine Court in James v. Valtierra $a^{5}$ reversed, upholding article XXXIV five to three with Justice Douglas not participating. ${ }^{6}$ None of the justices could see in the refedendum requirement a clear purpose to disadvantage blacks or other racial or ethnic minorities. But the three dissenters would have striken article XXXIV for inaking an explicit classification based on poverty. The concluding sentences of the dissent were to shape the popular reading of the Court's opinion:

Yet after observing that the article does not discriminate on the basis of race, the Court's only response to the real question in this case is the unresponsive assertion that "referendums demonstrate devotion to democracy, not to bias, discrimination, or prejudice." It is far too late in the day to contend that the Fourteenth Amendment prohibits only racial discrimination; and, to me, singling out the poor to bear a

2. See M. Anderson, The Federal Bulldozer 91-105 (1965); M. Harrington, Toward a Democratic Left 53-55, 101-02 (1968); B. Weissbourd, SegregaTION, Subsidies and Megalopolis 5-6. See also Norwalk CORE v. Norwalk Redev. Agency, 395 F.2d 920 (2d Cir. 1968); Contract Buyers League v. F. \& F. Inv., 300 F. Supp. 210 (N.D. Ill. 1969) (provisions of sales contracts for used housing challenged by black homeowners).

3. Valtierra v. Housing Authority, 313 F. Supp. 1 (N.D. Cal. 1970), rev'd sub nom. James v. Valtierra, 402 U.S. 137 (1971).

4. 313 F. Supp. at 4.

5. 402 U.S. 137 (1971).

6. The New York Times explained Justice Douglas' noninvolvement as follows:

"Justice William O. Douglas did not take part presumably because one of the lawyers in the case, Warren Christopher of Los Angeles, did legal work for Justice Douglas in connection with the impeachment investigation of him in the House of Representatives last year."

N.Y. Times, Apr. 27, 1971, § 1, at 22, col 6. 
burden not placed on any other class of citizens tramples the values that the Fourteenth Amendment was designed to protect. ${ }^{7}$

This passage can be read to imply that a majority of the Court is prepared to tolerate discrimination based on economic criteria, especially if it occurs with the support of an enthusiastic electorate. If so, the implications for zoning and other municipal regulations are significant: public endeavors by suburbs to exclude the poor or, in fact, anyone of modest means, may be safe from the strictures of equal protection.

Although Valtierra's brief majority opinion would have to be stretched considerably to cover so broad an imphcation, it was widely reported; journalists across the land had gleaned a message. If the Supreme Court of Earl Warren could be held to public ridicule as encouraging crime in the streets (Miranda and all that), the Burger Court could now be heralded or marked as a defender of the outer city and suburbs against unwanted newcomers. ${ }^{8}$ A court that permits people in San Jose to vote out welfare mothers cannot be expected to balk if New Canaanites want to zone out Puerto Ricans. This is what the press coverage of James $v$. Valtierra suggested to the avid newspaper reader. ${ }^{9}$

Among those who received this message was a city councilman in Torrance, California, ${ }^{10}$ a community bordering Los Angeles with a population of 134,584, of whoin 199 are nonwhite. ${ }^{11}$ Two days after

7. 402 U.S. at 145 (Marshall, Brennan \& Blackmun, JJ., dissenting).

8. Headlines in The New York Times announced Valtierra as follows:

"High Court Rules Voters May Block Housing for Poor"; "Backs, 5-3, California Law Requiring Public Approval of Low-Rent Projects"; "Race Role Discounted"; "Marshall Denounces Opinion Limiting Equal Protection Clause to Minorities."

N.Y. Times, Apr. 27, 1971, at 1, col. 8. The Phoenix Gazette, June 11, 1971, at 1, described the case thusly: "Nixon Won't Push Poor on Suburbs."

9. A general discussion of the Supreme Court's new image appeared in a $\mathrm{New}$ York Times article

The most obvious [conclusion] is that President Nixon has already succeeded in large part in his expressed goal of reshaping the Court. The votes of Chicf Justice Burger and Justice Harry Blackmun [are] consistently cast on the conservative side of the issues....

... [Many attorneys] regard the Court now as the Sanctuary of prosecutors, Government officials and those seeking to maintain things as they are now. By giving limited and narrow interpretation to the precedents established by the Warren Court without necessarily overruling thein directly, the new Court majority has turned the trend of the law in a more conservative direction. And the hitigants - often funded and supported by charitable organizations or public interest groups-who succeed im persuading lower court judges of the merits of their claims now frequently try to keep their legal issues out of the jurisdiction of the Burger Court.

Lewin, There Is No Mistaking the Swing of the Pendulum, N.Y. Times, June 27, 1971, $\S 4$, at 8 , col. 1 .

10. Torrance Councilman George Surber.

11. Bureau of the Census, U.S. Dep'T. of Commerce, 1970 Census of Popu- 
Valtierra hit the street he asked the city attorney whether the local electorate could vote on the low-rent housing being proposed for the Victor precinct in Torrance.

OGO Associates, an enterprising builder of low-income housing, ${ }^{12}$ had applied for a building permit to construct 86 units in a multifamily zone under section 236 of the National Housing Act. ${ }^{13}$ Under this section the mortgage interest rate on certain FHA-insured apartment projects may be subsidized down to one percent through an annual payment from the Department of Housing and Urban Development to the lender. These projects are privately developed, privately owned, privately financed, and subject to a full measure of property tax. By contrast, public housing is developed by a local public agency ${ }^{14}$ and must be exempted from local property taxes. ${ }^{15}$ As a first step toward providing low-rent public housing, a city must activate a housing authority, which Torrance has never done. The subsidy authorized by section 236 is not as deep as that provided for public housing: where public housing would accommodate a family of four with a $\$ 5,000$ income, a comparable 236 project would require an imcome of $\$ 6,750$. $^{16}$ Finally, federal law requires each public housing project to

lation, General, Population Characteristics, PC. (V2)-6 California (1971). The racial breakdown is 134,584 whites, 199 nonwhites, and 5,231 "other." According to the 1967 census, the average income is $\$ 10,904$ per year. Carl Busse of the Torrance Planning Departments estimated that the median income is around $\$ 10,000$ per year. Telephone interview with Carl Busse, Torrance Planning Departments, Aug. 3, 1971.

12. OGO Associates was forned in January 1970 and has developed 1,072 units of federally assisted housing, mostly under the turnkey leasing program described in text accompanying notes 129-31 infra. The principals are Samuel Oschin, fornerly Chairman of the Board, Empire Savings and Loan Association, who has also been a builder in southern California for 20 years; William K. Glikbarg, fornerly a partner in the Beverly Hills law firm of Swerdlow, Glikbarg, and Shimer; and Michael H. Oschin, a builder and developer of tract homes in southern California.

13. National Housing Act $\$ 236$, as amended, 12 U.S.C. $\S 1715 \mathrm{z}-1$ (1970). OGO Associates applied for a building permit on Apr. 30, 1971. OGO Associates v. City of Torrance, No. C 5254 (Cal. Super. Ct., Los Angeles County, Apr. 30, 1971).

14. United States Housing Act of $1937 \S 10(\mathrm{~h}), 42$ U.S.C. $\$ 1410(\mathrm{~h})$ (1970).

15. United States Housing Act of $1937 \mathrm{ch} .896, \S 1,50$ Stat. 888, as amended, Housing Act of 1959 \& 501, 42 U.S.C. $\$ 1401$ (1970).

16. The Act requires that most ( 80 percent) of the units built under this section house people whose incomes are no greater than 135 pereent of local public housing income eligibility limits. National Housing Act $\$ 236$, as amended, 12 U.S.C. $\S 1715 z-1$ (1970).

The bases for computing subsidies under public lousing and 236 are quite different and for each program rather complieated. The federal government subsidizes the entire capital cost of a public housing project. Through an agreement known as the annual contributions contract, HUD promises to make annual debt service grants for a period up to 40 years to cover the capital costs of a public housing project. United States Housing Act of 1937 \& 10, 42 U.S.C. $\$ 1410$ (1970).

In 1969, Congress enacted the Brooke Amendinent in an effort to ease the local housing authorities' burden of meeting soaring maintenance costs from rent collections. 
be approved by the host city council; no special local consent is required for a 236 project. Thus, the Torrance city council could not have stopped the project except by a last-minute rezoning of the parcel.

Despite the city attorney's carefully drafted analysis, indicating that article XXXIV and hence Valtierra applied only to low-rent public

The Brooke Amendment prescribed that public housing rent "may not exceed one-fourth of the family's income, as defimed by the Secretary" [The Housing and Urban Development Act of $1969 \S 213(\mathrm{a}), 42$ U.S.C. $\$ 1402(1)$ (1970)J, and expanded the scope of the annual contribution contraet as follows:

[T] he fixed contribution payable annually under any contract, although not limited to debt service requirements, shall in no case exceed a sum equal to the annual yield, at the applicable going Federal rate plus one percentum, upon the development or acquisition cost of the low-rent housing or slum-clearance project involved.

42 U.S.C. $\$ 1410$ (a) (1970). The italicized section was inserted by the Housing and Urban Development Act of $1969 \$ 212($ a), Pub. L. No. 91-152, 88 Stat. 379.

Also, in 1968 Congress authorized a special subsidy "not to exceed $\$ 120$ per annum per dwelling unit occupied by . . . a large family, or a family of unusually low income. . . United States Housing Act of $1937 \S 10$ (a), 42 U.S.C. $\$ 1410$ (a) (1970). Special aid to large families and families of unusually low income was authorized by the Housing and Urban Development Act of 1968 \& 209, 42 U.S.C. $\$ 1410$ (a) (1970). Earlier legislation had provided this special subsidy for units occupied by elderly families [Housing Act of $1961 \S 203,42$ U.S.C. $\S 1402(2)(1970)$ ] and displaced families [Housing Act of $1964 \S 402,42$ U.S.C. $\$ 1410(\mathrm{~g})(2)(1970)$ ].

For the $\S 236$ program, the maximum federal subsidy is equal to the difference between the mouthly payment for principal, interest, and mort. gage msurance premium which the project owner as a mortgagor is obliged to pay under the mortgage and the monthly payment for principal and interest such project owner would be obligated to pay if the mortgage were to bear interest at the rate of one per centum per annum.

The National Housing Act $\$ 236(c)$, as amended, 12 U.S.C. $\$ 1715 z-1$ (c) (1970). These subsidized interest reduction payments must be passed through to the tenants in the form of lower rents, but only to the extent that rent is reduced so that each family pays at least $25 \%$ of adjusted family income for rent. National Housing Act $\$ 236(f)$, 12 U.S.C. $\$ 1715 z-1$ (f) (1970). The maximum rent any family can be charged is the fair market rent for the dwelling unit. For the calculation of adjusted family incoine, see National Housing Act $\S 236(\mathrm{~m})$, 12 U.S.C. \& 1715z-1(m) (1970); NATIONAL INSTTTUTE FOR EDUCATION IN LAW AND POVERTY, HANDBOOK ON Housing LaW, ch. V, pt. III, 32-33.

The monthly rent for a section 236 tenant covers monthly maintenance and operating expenses, property taxes, and monthly payments for principle, $1 \%$ interest on the principal, and the mortgage insurance premium. See National Housing Act $\$$ 236(b), (c), (f), as amended, 12 U.S.C. $\$ \$ 1715 \mathrm{z}-1$ (b), (c), (f) (1970). Also, if the section 236 project is developed by a limited-dividend sponsor, the rent is calculated to allow the mortgagor a $6 \%$ return on his initial equity investment-roughly $10 \%$ of the project's replacement cost. See 24 C.F.R. $\$ 236.50$ (1971). The rent for the public housing tenant usually only pays for inonthly inaintenance and operating expenses, although there are occasions when rents are sufficient to repay a portion of the capital costs. Moreover, for public housing, the local governing body agrees to waive property taxes and, in turn, receives from the local housing authority a payment equal to $10 \%$ of the project's annual shelter rents. The Housing Act of $1937 \S \S 10(\mathrm{~h}),(\mathrm{i}), 42$ U.S.C. $\S \S 1410(\mathrm{~h})$, (i) (1970).

Through the use of rent supplement assistance, section 236 projects can house families with incomes in or near the public housing incoune range. At present, how. ever, HUD practice permits no more than $20 \%$ of the units in a section 236 project to 
housing and that a 236 project referendum would probably be unconstitutional, ${ }^{17}$ the council was determined to pursue the matter. Public interest had been aroused. A public hearing was conducted, with between 500 and 1,000 citizens in attendance, and-far from constituting a silent majority - the crowd reacted as if they were watching a melodrama. ${ }^{18}$ They booed the builder, cheered the protesting neighbors, and greeted any councilman's indication of opposition with loud applause. The upshot was the imposition of a moratorium on all apartinent construction in the area, ${ }^{19}$ pursuant to California Government Code section 65858. This section permits a municipality to enact an emergency ordinance prohibiting any uses that may be inconsistent with a contemplated zoning proposal. And a rezoning of OGO's site to ban garden apartments is precisely what the council had in mind.

OGO Associates is suing. ${ }^{20}$ They claim, inter alia, that section 65858 cannot be used to halt a particular project and that the section's requirements are not satisfied unless there is a proposal to modify the zoning regulations actually before the city council, planning commission, or building deaprtment at the time an emergency ordinance is adopted. Although the people in Torrance have been concerned about apartment development generally, OGO will argue that no proposal to change the zoning for this neighborhood was imminent and that section 65858 was therefore improperly invoked. ${ }^{21}$

be occupied by tenants receiving rent supplement assistance. Moreover, rent supplement assistance often cannot follow section 236 projects into suburban communities because of the local approval required for the rent supplement program.

17. The opinion of the Torrance City Attorney, Stanley E. Remelmeyer, dated May 20,1971 , is on file with the author. Subsequently, the California attorney general issued an opinion supporting this view. OP. CaL. ATt'Y GEN. No. 71-132 (Aug. 31, 1971).

18. See Campbell, Torrance Halts Housing Project, South Bay Daily Breeze, May 26,1971 , at 1, col 2. The proposed section 236 project for Torrance did generate substantial controversy. The Torrance South Bay Daily Breeze reported that on the night the Torrance City Conncil voted on an emergency 90 -day moratorium on building permits, residents "jammed the city hall conncil chamber, adjoining rooms, corriders and entrances." Id. Organized opposition to the section 236 project included a newly formed Victor Homeowner's Association and the Torrance Support Your Local Police Committee. Organizations speaking in favor of the subsidized housing were the Torrance League of Women Voters, the Torrance Human Relations Council, and the Torrance Chapter, American Association of University Women. See id. at 7, col. 1 .

A Daily Breeze report also indicated at least one proponent of the section 236 project was subjected to mild personal attacks: Councilman George Brewster said he had been the victim of "telephone threats, vicious letters" and that his child's bicycle had been destroyed at school over the issue. Id.

19. Torrance, Cal., Ordinance 2232, May 27, 1971.

20. OGO Associates v. City of Torrance, No. C 5254 (Cal. Super. Ct., Los Angeles County, April 30, 1971).

21. The issue of how far a community must have proceeded in its planning and how large an area the contemplated change must encompass before the city may 
Whatever the outcome, the Torrance reaction is only a little more immediate and emphatic than most. In cities everywhere, $\mathrm{Val}$ tierra has been construed as granting a license to halt low-income housing wherever it is not wanted. Public housing referendums may be initiated in some places where they never existed before. Efforts to repeal some existing state referendum requirements liave been stayed. And present referendum provisions that cover some forms of subsidized housing but exclude others may be amended and enlarged to encompass all government-assisted units. Finally, we may see an even bolder use of zoning and other land use laws in attempts to effect exclusionary purposes. Yet it seems scarcely possible that the series of race and poverty cases going all the way back to $B r o w n^{22}$ and Skinner ${ }^{23}$ are to lave no applicability in stemming this trend.

\section{B. The Prospectus}

I am persuaded that Valtierra signals no green light for any of these insidious steps. Recent opinions show the Court prepared to scrutinize a fair range of laws for impermissible differential effects among classes of persons. The basis for review, lowever, of any disadvantageous classification is the ordinary "reasonableness" standard, which, in skillful and ready hands, suffices nearly as well as the "compelling reason" formula used in claims based on racial discrimination. Mainly, the Court seems to have rejected the rhetoric that would convert judicial review into a ritualistic search for certain evil classifications. For example, not all cases with black litigants concern black people as a racial group, and the Court has come decisively to draw this distinction. Similarly, not all classifications based on wealth can be made suspect without surrendering our aspirations for consumer sovereignty and social mobility. Furthernore, some distinctions-among thein those resulting in severe deprivation to identifiable groups-will prompt rigorous judicial inspection quite apart from whether the litigants are black or can be said to stand for all poor people and only for poor people. ${ }^{24}$

properly invoke a moratorium has not been hitigated. However, in the cases that have sustained the general moratorium provision, comprehensive planning had proceeded rather far. See Anderson v. City Council, 229 Cal. App. 2d 79, 40 Cal. Rptr. 41 (1st Dist. 1964); Metro Realty v. County of El Dorado, 222 Cal. App. 2d 508, 35 Cal. Rptr. 480 (3d Dist. 1963). G \& D Holland Constr. Co. v. Marysville, 12 Cal. App. 3d 989, 91 Cal. Rptr. 227 (3d Dist. 1970) [discussed in text accompanying notes 192-95 infra], suggests that if a moratorium were imposed primarily to discourage a particular project, it would be impermissible. See also County of San Diego v. Williams, $126 \mathrm{Cal}$. App. 2d 804, 272 P.2d 519 (4th Dist. 1954).

22. Brown v. Board of Educ., 347 U.S. 483 (1954).

23. Skinner v. Oklahoma ex rel. Williamson, 316 U.S. 535 (1942).

24. Kramer v. Union Free School Dist., 395 U.S. 621 (1969), Harper v. Virginia 
The form of a classification continues to have significance-for example, whether it overtly mentions race or poverty, or identifies explicitly those against whom it is aimed. Also germane is the kind of classification involved-whether it impinges on any of a growing list of "fundamental" rights. A clear plurality of the justices would not confine the list to the traditional constitutional protections, such as speech travel, or criminal defense, but would extend it to such fields as welfare and divorce proceedings.

A third consideration of evident importance in recent cases has been the extent of the deprivation visited by the classification. ${ }^{25}$ Denying an indigent person the right to a divorce ${ }^{26}$ can be regarded as a greater hardship than the one inflicted by article XXXIV. Lastly, the uniqueness of the distinction counts. Is this the only group disadvantaged in this way, or is there merely a random or innocuous pattern affecting miners and Democrats today, shopkeeps and Legionnaires tomorrow? The more isolated the victim, the closer the scrutiny.

If this picture proves accurate, it will be especially encouraging for those concerned with housing. Judicial review that is responsive to a variety of indicia would be of special importance in zoning challenges, since the distinctions that these laws make are not neatly divided along familiar lines of race or poverty, even though zoning regimes may in fact disadvantage particular classes.

Justices are not appointed for their competence in evaluating locally drafted housing elements ${ }^{27}$ or imspecting the contours of a land use map. Persuading them that a community is in effect rationing land on an invidious basis or playing fast and loose with the rights of landowners, developers, would-be apartment dwellers, and young black couples will not be an easy task. Yet it is a task that would be made far more manageable by the Court's utilization of a formula, inchoate in Valtierra and other recent cases, that varies the degree of judicial scrutiny according to the form, kind, intensity, and uniqueness of the deprivation. There may be in Valtierra and the other cases decided this term more of help than harm to those who would increase access to housing.

Bd. of Elections, 383 U.S. 663 (1966), and Carrington v. Rash, 380 U.S. 89 (1965), may all be read as supporting this proposition. See also note 137 infra.

25. See Note, Exclusionary Zoning and Equal Protection, 84 HaRv. L. Rev. 1645, 1660 (1971).

26. Boddie v. Connecticut, 401 U.S. 371 (1971).

27. Section 701 of the Housing Act of 1954 was amended in 1968 [Pub. I. No. $90-468, \S 601,82$ Stat. 526 (codified at 40 U.S.C. $\$ 461(1970)$ )] to require that planning grants must include a housing element. A similar requirement, more explicitly defined, appears in CAL. Gov'T CoDe $\$ 65302$ (West 1966). These documents sometimes provide a standard by which a community's actual zoning decisions may be tested. 


\section{The Racial Aspects of Public Housing Referendums}

\section{A. Why Article XXXIV Was Not Deemed Racially Discriminatory}

In Valtierra the district court had relied on Hunter v. Erickson. ${ }^{28}$ In Hunter the United States Supreine Court invalidated an amendment to the Akron City Charter that would have prevented any ordinance regulating real estate on the basis of race, color, religion, or national origin froin taking effect without ratification by city election. Hunter had followed Reitman v. Mulkey, ${ }^{29}$ in which the Supreme Court affirmed a California supreme court finding that a state constitutional amendment was racially discriminatory. The amendment, known as Proposition 14, would have repealed existing fair housing legislation and barred the state or any of its subdivisions from passing any laws that limited the freedom of a property owner to sell or rent for any reason to whomever he chose.

To equate article XXXIV with the provisions erased by these precedents, plaintiffs' counsel needed to discount the more explicitly racial components of Hunter and Reitman. Thus, they argued that none of the three laws involved racial issues exclusively, yet each entailed racial implications. The plaintiffs in Valtierra and a companion case, Hayes v. Housing Authority, ${ }^{30}$ were on waiting lists for public housing in San Jose and were predominantly black or Chicano. There was testimony that a disproportionate share of housing occupied by Chicanos was delapidated or deteriorated. The same private property and free enterprise cluster of interests that had backed Proposition 14, the anti-open-occupancy annendment in Reitman, supported article XXXIV. Although opposition to open occupancy legislation was at least partially based on legitimate concerns, such as declining property values, potentially onerous administrative burdens, and interference with the broker-client relationship, open occupancy referendums had nonetheless been deemed pernicious. Appellees contended that article XXXIV should be similarly viewed, since the motives that prompted it were equally invidious. ${ }^{31}$

\section{The Illusion of a Presumption in Favor of Popular Democracy}

How did the three-judge district court go wrong in accepting this argument and perceiving Valtierra as Hunter in a new dress? Justice

28. Valtierra v. Housing Authority, 313 F. Supp. 1 (N.D. Cal. 1970), citing Huuter v. Ericksou, 393 U.S. 385 (1969).

29. 387 U.S. 369 (1967).

30. 313 F. Supp. 1 (N.D. Cal. 1970) (consolidated with the Valtierra opinion).

31. Plaintiff's Memorandum of Points and Authorities in Support of Complaints 
Black, who wrote for the Court in Valtierra, had dissented in Hunter. There, he found no constitutional basis for denying Akron voters the right to repeal any law, even a fair housing law. Nor could he locate a clear constitutional stricture against requiring a public vote for all future fair housing ordinances. ${ }^{32}$ The portion of his Hunter dissent that became a basis for the inajority opinion in Valtierra bears quotation:

Akron's repealing law here held unconstitutional, provides that an ordinance in the fair housing field in Akron "must first be approved by a majority of the electors voting on the question at a regular or general election before said ordinance shall be effective." The Court uses this granted right of the people to vote on their important legislation as a key argument for holding that the repealer denies equal protection to Negroes. Just consider that for a moment. In this Government, which we boast is "of the people, by the people, and for the people," conditioning the enactment of a law on a majority vote of the people condenins that law as unconstitutional in the eyes of the Court! ${ }^{33}$

In Hunter, Justice Black was the only dissenter and the only one among his colleagues to place so high a premiun on the democratic process. Yet 27 months later, he was empowered to write for the majority in Valtierra that "[p]rovisions for referendums demonstrate devotion to democracy, not to bias, discrimination, or prejudice."34

This much-quoted phrase has inisled some students of the Court to conclude that referendums might be approved after no more than perfunctory review. ${ }^{35}$ However, the search for a Valtierra rationale cannot

for Declaratory aud Injunctive Relief at 1-3, 12-21, Valtierra v. Housing Authority, 313 F. Supp. 1 (N.D. Cal. 1970).

32. 393 U.S. at 397.

33. $I d$.

34. 402 U.S. at 141.

35. In fact, some liberals have interpreted Valtierra as possibly condoning the use of economic classifications:

In our view the Supreme Court specifically decided that the mandatory referendum on public housing required by California law does not single out persons advocating low-imcome housing for procedural burdens which no other group in California must face in seeking to influence public decisions. In other words, the poor are not so uniquely disadvantaged by California law as to have been denied equal protection. The Court observed, in support of this conclusion, that mandatory referendunts are required for approval of state constitutional amendments and certain other local public actions; moreover "California statute books contain much legislation first enacted by voter initiative, and no such law can be repealed or amended except by referendum." We believe that the Court's legal conclusion was erroneous. But that is clearly the Court's holding and it was clearly influenced by the pecularities of California law and history.

The majority opinion, lowever, also inılied that even had the poor been singled out and disadvantaged by the mandatory referendum, the equal protection elause might not forbid such a special electoral burden, presumably on the ground that California's interest in assuring a high degree of plenary voting 
be halted at this egalitarian pass ${ }^{36}$; all three cases-Reitman, Hunter, and Valtierra-involved voter control, yet only in Valtierra was the enactment sustained. While Justice Black had dissented in all three cases, there was more than this even to his view-and therefore nccessarily to the majority's.

Students of the political history of public housing can only be relieved that not much attention need be given Justice Black's extreme deference to the referenduin process. Referendums to block public housing were organized in the early 1950's by the same interests that had op-

on local and state affairs was rational, particularly in the light of its rich history of referendums on many issues.

The decision tells us, then, that whatever may be the basic underlying rights of the poor with respect to access to decent housing, the mere submission of such an issue to the electorate does not deprive them of those rights without an examination of surrounding facts im regard to their needs and the housing policy of the locality. Of course, in situations where race is explicitly involved in the submission of issues to the electorate, such a referendum on its face does have a stigmatizing impact which impairs the rights of racial minorities without regard to the substantive imjury to the rights of such a minority. Therefore, in brief, the Valtierra decision may say nothing more than that a referendum requirement that does single out the interests of a group other than a racial minority does not on its face "add insult to injury"-that is, deny equal protection of the law.

The Court, having disposed of the case on the due process issue, never reached the question of "injury"- the core questiou that will ultimately have to be confronted: What are the constitutional obligations of localities to provide decent honsing for the poor and racial minoritics, either by affirmative action or by undoing the result of negative governmentally inposed landuse controls that frustrate private efforts to meet these needs?

National Urban Coalition, The Meaning of the Supreme Court Decision in James v. Valtierra, May 28, 1971, at 3, 5.

36. In English v. Town of Huntington, N.Y.L.J., Sept. 9, 1971, p. 1, col. 5, the Second Circuit had occasion to consider the meaning of Valtierra. Suit had been brought on behalf of all black and Puerto Rican residents, claiming a denial of equal housing opportunities as a result of the town's urban renewal and other programs. Specifically at issue was a request for a temporary injunction to bar enforcement of building codes against the owners of slum houses occupied by minority people. While the judges disagreed on how to interpret Valtierra, none thought the fact that a referendum was involved had particular significance.

Judge Friendly, writing the majority opinion, noted that the disproportionate impact of a housing code enforcement program on minority occupants was itself insufficient to prevent the town from acting. He cited James v. Valtierra for this proposition: "[T] he mere fact that a requirement, otherwise proper, may have a greater impact on the poor, does not render it invalid under the Equal Protection Clause."

Dissenting, Judge Oakes conceded that Valtierra could "be read as the majority apparently reads it, to permit discrimination against the poor, despite past holdings," but said that "no one has suggested that [Valtierra] erodes the vitality of Suprcmo Court decisions against racial discrimination." In a footnote he indicated a preference for reading Valtierra "more narrowly as approving a statewide referendum requireinent for investment in low rent public housing in a state where other referenda are used on a variety of subjects." He was, however, concerned that the Supreme Court majority opinion in Valtierra did not "seem to answer the point made in the dissent, so that one might question whether the equal protection clause any longer applies to prevent discrimination against the poor as such." 
posed the expansion of the public liousing program ever since the end of World War II. ${ }^{37}$ Largely through the efforts of the National Association of Real Estate Boards, the National Association of Home Builders, and the United States Savings and Loan League, no major public lousing legislation was enacted until 1949 when a heavily Democratic Congress led by a Democratic President managed to enact an authorization for 810,000 new units. ${ }^{38}$ As soon as the bill was passed, the Washington offices of several of these housing associations sent appeals to their local chapters to fight against the implementation of the program. Among the local efforts was Proposition 10, which was to become article XXXIV.

Carefully analyzing this and other referendum campaigns, Professor Leonard Freedman concluded:

The referendum campaigns, of course, demanded tactics very different from those of traditional lobbying. The referendum, after all, was originally designed as a way of preventing control by small numbers of professionals and activists and of placing the decisions in the hands of the many. By and large, the results have not provided an overwhelming demonstration of the validity of direct rather than representative democracy. Power has tended to shift to the few who have the money needed to hire the specialists in the arts of massmedia persuasion. The public housing referendun cainpaigns were painfully impressive illustrations of this new reality. ${ }^{39}$

\section{The Function of Form in Race Cases}

Hunter was the only one of the three cases with an enactment

37. L. Freedman, Public Housing: The Politics of Poverty 66 (1969) (hereinafter cited as FreEDMAN).

38. Housing Act of $1949 \S 305$, Pub. L. No. 171, ch. 338, 63 Stat. 413, 427 (codified at 42 U.S.C. $\$ 1410$ (1970) ). In a letter dated July 18, 1950, President Truman requested the Housing and Home Finance Agency to reduce the construction of lowrent public lousing units to 30,000 for the first 6 months of the fiscal year 1951 due to the Korean einergency. See House Comm. on Banking and Currency, Basic Laws and AUthortties on Housing and URban Development, 91st Cong., 2d Sess. 2 (1970), for a chronicle of the cutbacks that resulted in a 20-year lag to realize the 1949 goals.

39. FREEDMAN 70-71. To be sure, there were interest groups aligned in favor of public housing: labor unions, church groups, federal officials, womens' organizations, NAACP, National Urban League, and other citizens and civic groups. To committed plurahsts, this could be comforting evidence that no one or combination of interest groups dominates the rest. To others, the outcomes in public housing referendum campaigns might serve as proof that ours is a society governed mainly by business interests. Professor Freednian surmised that "the group balance theory ultimately provides a less satisfactory interpretation ... than the opposite thesis." Id. at 78. But whatever one concludes either about cogence of the group-balance or business-domination theories, or the outcome in this situaton, a study of what has actually happened iu referendum campaigns is sobering enough to keep many from assenting to Justice Black's heady tribute to the referendum process and democratic values. 
worded explicitly in terms of "race, color, religion, national origin, and ancestry." For Justices Harlan and Stewart this seems to have been decisive. Having voted to uphold Proposition 14 for being "by its terms inoffensive,"40 they were able to concur in striking the Akron ordinance as "discriminatory on its face." 41

The implications of this position moved liberal critics of the Court to passionate rebuttal. Professor Charles Black put the argument concisely: Suppose California's amendment had sought to preserve freedom of choice for owners "to decline to sell . . . to any Negro."42 Responding to his own lyypothetical, the professor asked, "Has the state, by generality of language, succeeded in validly doing to Negroes what it could not do to Negroes ex nomine? Has, at last, the hand been quicker than the judicial eye?"43 In the Reitman dissent he saw an overzealous effort to separate state or public from nonstate or private discrimination. In a very important sense his analysis was prophetic:

One sometimes senses in the air an inarticulate inajor premise that the "equal protection" obligation defines a kind of game, in which the object is for the state to see what it can get away with. If all a state has to do to avoid being tagged with a "denial of equal protection" is just barely to be absolutely "neutral" as between Negroes on the one hand and on the other those who want to isolate them, then the rule of the game is that we must search the record each time to find solne way in which more-_"significantly" more-has been done. If that is the game, then Reitman illustrates a state's failure to win, I think, but not, concededly, by a mile. A little more "neutrality" next time, a little less obvious favoring of the discriminator, and who knows? As long as that is the garne, what we can look forward to is a succession of cliffhangers. ${ }^{44}$

And the cases this term have been cliffhangers.

How could such thoughtful men as Justices Harlan and Stewart be enticed by form, by whether the word "Negro" happens to appear on the face of a law? Professor Black could see only one legitimate reason: that the fourteenth amendinent might otherwise be expanded until it would regulate "the genuinely private concerns of man." 45 But this the Court could readily prevent should avid equal-protectionists try to go too far. If this were the only reason to distinguish laws that ex-

40. Reitman v. Mulkey, 387 U.S. at 392.

41. Hunter v. Erickson, 393 U.S. at 395. (1967).

42. Black, Foreword to The Supreme Court 1966 Term, 81 HaRv. L. Rev. 69, 78

43. Id. at 79 .

44. Id. at 99.

45. Id. at 100 . 
pressly single out blacks from those framed more generally but having comparable effects, it could be dismissed perfunctorily. But it is not.

One practical virtue of the Harlan-Stewart position is that it will often put those who would discriminate to an arduous burden without committing the Court to a dangerously aggressive and sometimes futile engagement. Law-abiding bigots are forced to run the risks of inexact classifications. As the Hunter majority stressed:

The automatic referendum system does not reach housing discrimination on sexual or political grounds, or against those with children or dogs, nor does it affect tenants seeking more heat or better maintenance from landlords, nor those seeking rent control, urban renewal, public housing, or new building codes. ${ }^{46}$

Dog owners and parents, Republicans and the Gay Liberation Front were all potentially disadvantaged by the California law, for it barred the state and all its subdivisions from domg anything to prevent landlords and homeowners from refusing to sell or rent as they, in their absolute discretion, chose. In contrast, the Akron law created a special hurdle only for fair housing advocates who would ban discrimination based on "race, color, religion, national origin or ancestry."

Admittedly, pernicious ends can sometimes be achieved by laws worded generally. The short answer to this possibility is that the Reitman dissenters seem quite prepared to confront apparently neutral laws in order to assess whether their purposes and effects are invidious. ${ }^{47} \mathrm{Un}$ fortunately, the choice for the Court at times may be restricted either to writing decrees that will be openly defied or to constructing rules that have a gaming chance of encouraging ostensible complance. Emphasis on forn may lead legislators to play like small children trying not to get caught in embarrassing poses behind the bushes. They are compelled to conduct themselves always with a mind to saying, “Oh, no, we weren't doing that. We were just playing doctor and

46. 393 U.S. at 391.

47. Although the Court has now determined that article XXXIV on its face is "neutral," suppose a particular community could be shown to have utilized article XXXTV as part of a determined effort to confine or exclude a racial or ethnic minority. This will always be a hard proposition to substantiate. Probably most courts would regard it as a variant of the problem in Palmer v. Thompson, 403 U.S. 217 (1971). A community is ordinarily free to close public facilities but not to run them on a segregated basis. Similarly, article XXXIV referendums are generally permissible but not as part of a pattern of racial exclusion. Just as some of the Justices of the Supreme Court were prepared to consider evidence of motivation in Palmer, some judges will waive the usual proscription of motivation testimony and permit litigants to show racial bias in the conduct of a particular referendum. Others can be expected to take the majority's position in such close cases as these. It should be noted, though, that the most exclusionary communities are likely never to be challenged on article XXXIV referendums for the simple reason that they will not have activated housing authorities and thus will never have occasion to stage a referendum in the first place. 
nurse." Even if this were all the Court accomplished, it would not be trivial. Effective moral discourse often begins when authority figures provide guidance as slight as mild censure. Even deviants who alter their behavior only by paying lipservice to constitutional norms are drawn into the law's web instead of standing outside of it.

\section{The Crucial Distinction Between Racist Laws and Laws Affecting the Interests of Black People}

Except for those who object that all laws made in the United States are necessarily racist, ${ }^{48}$ no one contends that the fourteenth amendment ought give certain imterest groups a carte blanche immunity from

48. A recent statement of this position was a letter reprinted in the N.Y. Times, Aug. 1, 1971, \& 6 (Magazine), at 10, col. 1:

Nat Turner was asked to confess to crimes of murder and other connected charges before being hung. He indicated that he would so that he could seize the opportunity to make public these sentiments: "I've been asked to confess . . . to what??? I simply don't feel guilty, I have ventured iny life for the deliverance of my kind, I am a willing sacrifice to their cause. I have failed, and if you gentlemen would render me a favor you would take me out and hang me immediately." Another pointed exannle of how blacks view what the interpreters of society term crime can be had by recalling a later (1850) statement accredited to Martin Delaney: ". . . my house is iny castle. If any inan approaches my house in search of a slave I care not whom he may $\mathrm{be}$, whether constable or sheriff, magistrate or even Judge of the Supreme Court. If he crosses the threshold of my door and I do not lay him a lifeless corpse at my feet $I$ hope the grave may refuse my body a resting place." Fngitive slaves were criminals!! Anyone offering them aid was also considered part of the criminal act, according to the accepted standards of so-termed Amerikan society. These are parallels from history, valuable in that they have undoubted relevance upon the ingrained attitudes of two sections of the people whose real interrelations have changed in name and form only.

The question "Aren't any black people guilty of crimes in Amerikan society?" can best be answered by stating that the first crime is attempting to establish society above society, and then seriously questioning whether blacks have ever been any part of Amerikan society. I say we haven't. History states that we haven't. We're captives of this thing termed Amerikan. As such it is and has always been onr obligation to resist; resistance to unjust bonds, organized injustice, can never be interpreted as crime, be it individual resistance or organized mass resistance. Is it criminal for the black mine worker in the Union of South Africa to steal a diamond when he can, or for the workers in mass to take the mine? Were the Jews of Warsaw 1944-45 criminals?

The men who live above and at the center of Amerikan corporativism understand clearly the issue at question. Through their machinating, any activity can be inade to seem criminal. Most crimes are economic in nature85 per cent, in fact. These figures will alter as the revolution upstages, bnt the underlying motive will still be economic. Consequently the realistic situation is one where a very small knot of men and women are protecting "their" constitutional right to own or control the means of the people's snbsistence by defining criminality. The relatively small percentage of what is left-thrill crimes, or as your question runs: "the Black inan who rapes and murders a Black woman." Every revolutionary theoretician and psychiatrist accepts as elementary the tendency of violence to turn inward when the oppressed can find no externalization, "the collective autodestruction" phenomenon. Again the basis is economic oppression or the effects of a dying civilization tied to an economic arrangement that was decadent 100 years ago. Part of the myth that we must destroy is that "the people" reduced to a state of inexplicable misery 
the incidental hazards of the political process. The predicate of Professor Black's reading of Reitman is that "a racial group [was] in a political duel with those who would explicitly discriminate against it as a racial group. ..."49 Almost any minority interest, whether defined in terms of race, class, vocation, or avocation, will be adversely affected by a host of laws. How are we to determine when the interests of black people as a racial group are being affected adversely?

The opinions are written in terms of motivation and purpose, impacts and effects, facial content and neutral principles. When a racial classification is used directly, we liave an easy case and a compelling rationale must be shown for its use. Once we leave the facial content cases, however, and are no longer confronted with denials of access to public (or private) facilities solely on the basis of skin pigmentation or ancestry, we are fairly at sea. On this count, Valtierra was deemed an easy case by the Supreme Court. Although three Justices (and possibly four) would have stricken article XXXIV for discriminating on the basis of wealth, none could accept the racial argument that had won Reitman and Hunter.

Why were all the Justices able to conclude that the racial element in the Akron charter amendment or Proposition 14 (the anti-open-occupancy provision) was greater than the racial element in the public housimg referendum situation? The attorneys for appellant suggested a number of ways to distinguish the record on article XXXTV from that involved in the earlier cases: "Article XXXIV repeals nothing, it is not expressed in terms of race or discrimination, it had no unconstitutional motive, and it has no unconstitutional effect."50 In both the Akron amendment and Proposition 14 situations, the call for a popular referenduin was partly an effort to repeal open occupancy provisions already on the books. The appellants traced the beginnings of arti-

still have a choice of action. Invariably their response will take some form of violence. I term this violence, individual or collective, not crime but antithesis. "Violence is the midwife of every old society pregnant with a new one."

Society above society has had 7,000 years of trial. It has never worked. Pure totalitarianism is impossible-all so-called criminal action is governed by cause and effect, as is everything material. All criminals are victims of the attempt to maintain hierarchy. Any other conclusion denies original innocence, or in effect advances that men are criminals before they are born.

George Jackson

San Quentin Prison

June 11, 1971

Mr. Jackson was shot during an apparent escape attempt on Aug. 21, 1971. L.A. Times, Aug. 22, 1971, § 1, at 1, col. 5. See also T. Wicker, Death of a Brother, N. Y. Times, Aug. 24,1971 , at 37 , col. 1 .

49. Black, supra note 42 , at 82 .

50. Brief of Appellant at 15, Virginia C. Shaffer, No. 1557 (N.D. Cal. June 3, 1970) (emphasis added). 
cle XXXIV, by contrast, to California's constitutional requirement that major indebtedness by any "city, county, or school district" be imcurred only on a vote of the electorate. ${ }^{51}$ Despite a 1939 California supreme court ruling that local housing authorities are exempt from this requirement since they are neither cities nor counties, ${ }^{52}$ and the fact that federal, rather than state or local, funds meet the capital costs of public housing, ${ }^{53}$ the properties do involve costs to the local community, as they are largely tax-exempt. ${ }^{64}$ Article XXXIV can thus be styled a part of the long California tradition of public referendums on fiscal matters.

According to appellant, there were a host of legitimate policy reasons for placing the issue of public housing before the electorate. Public housing has tended to concentrate poor people in certain locations and has often been attacked for its institutional design and mammoth size. ${ }^{55}$ What is more, there was probably no disproportionate inhibition since 69 percent of the referendums, covering 52 percent of the proposed units, had yielded affirmative votes-a figure comparable to the returns on school bond issues. Even if the referendum requirement had stifled the use of public housing in California, appellant's counsel contended that no obligation to provide low-rent public housing exists and that the state is, therefore, relatively free to attach conditions to its development. Furtherniore, although this one program, low-rent lousing, is subject to referendums, many other housing programs for poor and moderate-incoine families are not covered by the referendum requirement.

The Supreine Court agreed that "California's entire history demonstrates the repeated use of referendums to give citizens a voice on questions of public policy." ${ }^{\text {se }}$ Appellees had pointed out that although the general referendum requirements prevalent in California comınunities provide an inchoate right for public approval of legislative acts, they

51. CAL. Const. art. XI, § 18.

52. Housing Authority v. Dockweiler, 14 Cal. 2d 437, 457, 94 P.2d 794, 805 (1939).

53. Note 16 supra describes the funding for public housing.

54. See note 16 supra. Daniel Sachs, General Counsel of the New Haven, Connecticut Housing Authority, estimates that in lieu payments range from $1 / 4$ to $1 / 3$ of the property taxes the City of New Haven would collect from public housing projects. Telephone conversation, Aug. 5, 1971.

55. J. Bellush \& M. Hausknecht, Urban Renewal: People, Politics, AND Planning 514-16 (1967); H. Sarisbury, The Shook-Up Generation 71-73, 42591 (1958); ShorR, Slum aNd Social Security 110-11 (1963); Huxtable, Model Cities Construction to Start Here by Fall, N.Y. Times, April 19, 1968, at 43, col. 1; Oser, Residential Architecture Disturbs Awards Jury, N.Y. Times, June 27, 1971, § 8, at 1, col. 6; Ledbetter, Public Housing-A Social Experiment Seeks Acceptance, 32 LAW \& CONTEMPP. Prob. 490 (1967).

56. 402 U.S. at 141. 
seldom demand affirmative approval. To this the Court was able to respond that under California law, "[m]andatory referendums are required for approval of state constitutional amendments, for the issuance of general obligation long-term bonds by local governments, and for certain municipal territorial annexations." ${ }^{.57}$ The Court made no comment, however, on appellant's assertion that the referendum had no unconstitutional effects. Its fimding that article XXXIV had at least some justifiable basis meant that the Court did not have to reacli this issue once it liad decided that the classification was not suspect and, inferentially, that no fundamental rights were prejudiced.

\section{B. What Could Make a Public Housing Referendum Racial Legislation?}

Under what circumstances could such a referendum be enacted elsewhere and be free from successful attack as racial legislation? And how could particular referendums be set aside even in California? In determining that the California referendum requirement was not a subterfuge for racial discrimination, the Court looked at the history of the referendum. California has been a referendum state in one degree or another since its inception. Virtually all legislative decisions are potentially subject to the public initiative and referendum, refornus stressed by clean-government advocates decades ago as a means of checking political corruption.

Manifestly, a state with no referendum tradition would have trouble explaining the creation of a special election for low-rent lousing. And if Congress voted to make all public housing projects fully subject to local property taxation, the one similarity between public housing and the other matters for whicl automatic referendums are held in California would disappear. Absent these conditions, only clear proof of overt racism in the promulgation of the referendum would lead to its being set aside, and even this might be insufficient.

Lately, the Supreme Court and a few lower federal courts liave indicated the ways by which they are prepared to distinguisl laws affecting black people as a racial group from those that may liarm black people im the ways that other interest groups are scarred in political frays. In a case concerning a school desegregation plan, Swann v. CharlotteMecklenburg Board of Education, ${ }^{58}$ Chief Justice. Burger wrote for a unanimous court:

It does not follow that the communities served by such systems will remain demographically stable, for in a growing, mobile society, few will do so. Neither school authorities nor district courts are constitu-

57. 402 U.S. at 142.

58. 402 U.S. 1 (1971). 
tionally required to make year-by-year adjustments of the racial composition of student bodies once the affirmative duty to desegregate has been accoinplished and racial discrimination through official action is eliminated from the system. This does not mean that federal courts are without power to deal with future problems; but in the absence of a showing that either the school authorities or some other agency of the State has deliberately attempted to fix or alter demographic patterns to affect the racial composition of the schools, further intervention by a district court should not be necessary. ${ }^{60}$

This statement from Swann reaffirms Gomillion; if a public agency deliberately attempted to fix demographic patterns to affect racial composition, the Supreme Court would be aroused to action. But the recently decided Jackson, Mississippi, swimming pool case, Palmer $v$. Thompson, ${ }^{60}$ is an example of municipal action with strong racial overtones that the Court nevertheless refused to overturn.

Subject to a court decree ordering the imtegration of all public facilities, Jackson, Mississippi, closed its swimming pools but kept open its parks, golf courses, auditoriums, and city zoo. Only the pools were losing money. ${ }^{61}$ From one perspective this may look like an attempt to thwart the desegregation order by closing the one facility where bodily contact between blacks and whites could most readily occur. Yet, if Jackson's tax system-like that of many cities-is highly regressive, it may be that black taxpayers are among those most burdened with the costs of maintaining the pools.

What divided the majority and the dissent in Palmer v. Thompson were ostensibly the differing weights they were prepared to place on legislative motives. Justice White, joined in dissent by Justices Brennan and Marshall, concluded:

The circumstances surrounding [Jackson's] action and the absence of other credible reasons for the closings leave little doubt that shutting down the pools was nothing more or less than a most effective expression of official policy that Negroes and whites must not be permitted to mingle together when using the services provided by the city. ${ }^{62}$

But to Justice Black, writing for the Court, it was nearly impossible to ascertain the "dominant" motive:

Here, for example, petitioners have argued that the Jackson pools were closed because of ideological opposition to racial integration in

59. Id. at 31-32.

60. 403 U.S. 217 (1971).

61. For several years the pools for whites in Livingston, Battlefield Park, and College Park and the pool for Negroes in College Park had expenses of $\$ 10,000$ each against revenues of $\$ 8,000$ each for the white pools and $\$ 2,500$ for the Negro pool. Palmer v. Thompson, 419 F.2d 1222, 1231 (5th Cir. 1970) (Wisdoin, Brown, Tuttle, Thornberry, Goldberg \& Simpson, J.J., dissenting).

62. 403 U.S. at 241. 
swimming pools. Some evidence in the record appears to support this argument. On the other hand the courts below found that the pools were closed because the city council felt that they could not be operated safely and economically on an integrated basis. There is substantial evidence in the record to support this conclusion. . . . Furthermore, there is an element of futility in a judicial attempt to invalidate a law because of the bad motives of its supporters. If the law is struck down for this reason, rather than because of its facial content or effect, it would presumably be valid as soon as the legislature or relevant governing body repassed it for different reasons. ${ }^{63}$

The majority's concerns are understandable but not insurmountable. Why demand an allegation that racism is the "dominant" motive, and why rely on motivation alone? If racism is present in any substantial degree, this alone might justify an exacting scrutiny of the legislation. ${ }^{64}$ And racism need not be sought exclusively in the events precipitating the questioned enactinent. The historical context may also be revealing, as past cases have held. As for the problem of futility, if the Court had really taken the fiscal argument seriously, it would surely have scrutinized the city's projection of continued losses. In years past the pool used mainly by blacks was the biggest money loser. ${ }^{65} \mathrm{~A}$ policy run purely along efficiency lines would probably have dictated closing only the most costly pool first to see if demand might be shifted to the reinaining pools in a volume sufficient to cover operating costs. In any event, even the sham of an efficiency analysis followed by a year or two of official effort to make the pools pay their own way would take some of the sting out of the apparent racial slur that the Court seemed willing to tolerate.

Although Justice Blackmun and Chief Justice Burger jomed the majority in Palmer, each wrote a separate concurrence to underline his special concerns with the case. The thrust of their observations is summarized in the following excerpts from the Chief Justice's concurrence:

We would do a grave disservice, both to elected officials, and to the public, were we to require that every decision of local governments to terminate a desirable service be subjected to a microscopic scrutiny for forbidden motives rendering the decision unconstitutional. ${ }^{\circ B}$

The Chief Justice was hesitant to lock in a public sponsor. This "would plainly discourage the expansion and enlargement of needed services

63. Id. at $224-25$.

64. A persuasive case for this proposition is made by Ely, Legislative and Administrative Motivation in Constitutional Law, 79 Y ALE L.J. 1205, 1266-69 (1970).

65. See note 61 supra.

66. 403 U.S. at 228. 
in the long run." ${ }^{07}$ Given that Palmer was a 5-to-4 decision, and Justice Blackmun and Chief Justice Burger sided with the majority for the reasons noted, the case was close indeed.

A pair of Supreme Court voting rights cases provide a somewhat clearer illustration of just how explicit and official racism must be to justify striking down otherwise reasonable laws. In Whitcomb v. Chavis, ${ }^{68}$ the Court held 6 to 3 that the use of multimember districts was acceptable for Marion County, Indiana. But, in Connor v. Johnson, ${ }^{69}$ a similar arrangement was held not suitable for Hinds County, Mississippi. We can infer, then, that a seemingly neutral classification, in order to be labeled invidious, must be accompanied by a particularly grim history of discrimination. What else distinguishes Hinds County, Mississippi, froin Marion County, Indiana? The Whitcomb district court had found that Marion County's multimember district did result in underrepresentation of ghetto blacks

because the proportion of legislators with residences in the ghetto elected from 1960 to 1968 was less than the ghetto's proportion of the population, less than the proportion of legislators elected from Washington Township, a less populous district, and less than the ghetto would likely have elected had the county consisted of singlemember districts. ${ }^{70}$

However, this was not attributable to any "schemes allegedly conceived or operated as purposeful devices to further racial discrimination."71 Rather, the Court assigned the underrepresentation to the ghetto's overwhelmingly Democratic voting pattern-Republicans had won all but one election since 1960. Justice White, who drafted the opinion, suspected that the poor blacks of the ghetto were no more underrepresented than other voters or interest groups in Marion County with allegiance to the Democratic Party. If every interest group were afforded the protection ghetto blacks were seeking, "it would be difficult for a great many, if not most, multimember districts to survive analysis." 72

After Valtierra was handed down, there were some Monday morning quarterbacks prepared to fault the appellees for not having made a better effort to indict article XXXIV for racism. Why didn't they show how many people on public housing waiting lists are blacks and Chicanos? Why didn't they bring forward evidence of racial prejudice that had tainted particular referendums or the enactment of article

67. $I d$.

68. 403 U.S. 124 (1971).

69. 402 U.S. 690 (1971).

70. 403 U.S. at 148-49.

71. Id. at 149.

72. Id. at 156. 
XXXIV itself? Whitcomb $v$. Chavis suggests how futile these offers of proof would have been. Statistical inferences may have worked well in jury selection cases where random selection may be the only equitable basis. ${ }^{73}$ But when states decide how to draw election district boundaries or which matters to subject to automatic referendums, more than differential impact needs to be shown. And Palmer (the swimming pool case) teaches that motivation alone may not be sufficient. To brand these types of acts as racist, a historical context, an invidious objeetive, and a probable pernicious effect may all be required. A case that rests on only one of these elements will likely be consumed by the goblin from the land of neutral principles, which is not to say that so weak a case does not deserve its fate.

If a referendum requirement were to be proposed in a state with a history different from California's, and if that enactment were accompanied by evident racial enmity, the new law might be on shaky legal ground. (Recall the special basis for the Palmer concurrences of Chief Justice Burger and Justice Blackmun.) Conversely, a state with a referendum tradition and a temperate and discreet citizenry might well extend its referendum apparatus to public housing. And even a touch of racism miglit be tolerated in a body politic heavily clothed in a long referendum experience.

\section{James v. Valtierra, Zoning, and Race}

By this time readers of liberal persuasion must surely be impatient to know how anyone can take solace in the Court's firm determination to separate laws with statistically discernible racial effects from laws embodying racial prejudice. It is important to recognize that a single law, unless maliciously conceived and demomacally executed, will rarely bear uniformly on the interests of black people. In a Democratic year, multimember districts for Marion County might enhance the poltical fortunes of a (disproportionate?) number of black candidates. The voters of Compton, California, with its largely black population, ${ }^{74}$ might value the opportunity to defeat an article XXXIV referendum in order to preclude school impaction, keep private property on the local tax rolls, maintain as much land as possible in the community for job-creating and revenue-generating land uses, and discourage the further immigration of poor people from neighboring cities with greater capacity to support them. I do not mean to imply

73. See, e.g., Turner v. Fouche, 396 U.S. 346 (1970).

74. Compton is $71 \%$ black. 1970 Census Data, Characteristics of Cities and Unineorporated Places, First Summary Report; A Joint Study of the Southern California Regional Information Study and the Los Angeles County Regional Planning Commission, SCRIS Report \# 5 (March 10, 1971). 
that Compton should or would do this, or to suggest that I know how to balance the equities in Marion County. This is precisely the difference between claiming to know what is best and being satisfied with what is reasonable. For the courts to intrude in disputes that might eventually divide black people among themselves and for which no guiding principles exist to justify court involveinent save that black people are affected by the outcoine, would be more than absurd. Such a misgnided intrusion might well hamper judicial recognition of new areas where judicial energy is needed.

Zoning is certainly among these areas. Some zoning disputes arise from nothing more than the old, familiar racism entering the parlors of the land use game. To keep the record straight, zoning was used as a device for racial exclusion even before it became popular as a means of separating incompatible land uses. As early as 1890 the city and county of San Francisco passed an ordinance that would have required all its Chinese residents to leave what is approximately Chinatown within 60 days and to relocate either outside the city limits or in a specially designated zone (an industrial area). ${ }^{75}$ Federal District Judge Sawyer gave the ordinance the short shrift it deserved. ${ }^{70}$

The next phase in exclusionary zoning saw the adoption of superficially neutral laws to achieve results not much different from those that had been sought in San Francisco. Louisville's provisions were typical in providing for the compulsory separation of the races by prohibiting a black from living where the greater number of residences were occupied by whites and barring whites from blocks occupied predominantly by blacks. ${ }^{77}$ Despite its ostensible neutrality the Supreme Court found the ordinance "in direct violation of the fundamental law enacted in the Fourteenth Amendment of the Constitution preventing state interference with property rights except by due process of law."78 The case was Buchanan v. Warley, ${ }^{70}$ decided in 1917years before the Court sustained comprehensive zoning in Village of Euclid v. Ambler Realty Co. ${ }^{80}$

Recent zoning cases continue to show that those communities determined to subvert zoning to exclusionary aims are only a little more inventive than their predecessors. The developer of interracial housing

75. In re Lee Sing, 43 F. 359, 360 (N.D. Cal. 1890).

76. Id. at 360-62.

77. See, e.g., State v. Gurry, 121 Md. 534, 88 A. 546 (1913) (upholding Baltimore's segregation zoning ordinance); Harden v. City of Atlanta, 147 Ga. 248, 93 S.E. 401 (1917); Carey v. City of Atlanta, 143 Ga. 192, 84 S.E. 456 (1915) (both upholding the Atlanta ordinance).

78. Buchanan v. Warley, 245 U.S. 60,82 (1917).

79. 245 U.S. 60 (1917).

80. 272 U.S. 365 (1926). 
or of housing for black people in previously white areas can be put to special hurdles by building inspectors, zoning administrators, subdivision regulators, planning commissioners, and city councilmen. ${ }^{81}$ Perhaps the most topical of the decided cases has been Kennedy Park Homes Association, Inc. v. City of Lackawanna. ${ }^{82}$ Retired Justice Clark, sitting by designation, wrote the Second Circuit opinion. (Recall that he dissented in Reitman along with Justices Black, Harlan, and Stewart.) In a three-ward city of 28,657 , the First Ward contained $98.9 \%$ of Lackawanna's nonwhite citizens, the most dilapidated housing, and the noxious Bethlehern Steel Company with its more than 20,000 employees. When it was first publicly announced that a lowincome, interracial housing project was proposed for a site in the Third Ward, there were threats of violence against blacks. The city tried to rush through a rezoning of the site for open space and parks and imposed a moratorium on all new construction. The rationale: a longstanding inadequacy of sewage facilities. On the record, city officials had for years been manipulating land use policies effectively to confine black people. The evidence suggested that if the proposed project had been conventionally financed and scheduled for white occupancy, it would have cleared the local land use hurdles. Citing the series of official acts to enforce patterns of residential segregation, the district court overturned the city's refusal of a building permit ${ }^{83}$ and the Second Circuit affirmed. ${ }^{84}$

It would be a fatal error, however, to assume that all zoning controversies are variations on the theme of Lackawanna. The courts could, of course, regard every move to block a low-rent housing project as an instance of exclusionary zoning. In all probability the consequences of such a policy would fall on the iniddle-income homeowner in older residential areas. Ever since Buchanan was decided, deed restrictions have been utilized to achieve ends that zoning could not. Racially restrictive covenants have been refused enforceinent since Shelley v. Kraemer, ${ }^{85}$ but no court has stricken the sorts of covenants

81. Deerfield Park Dist. v. Progress Dev. Corp., 22 IIl. 2d 132, 174 N.E.2d 850 (1961), aff'd on retrial, 26 Ill. 2d 296, 186 N.E.2d 360 (1962), cert. denied, 372 U.S. 968 (1963) (condemning property for the sole purpose of preventing subdivisiou for sale of homes to blacks is a denial of equal protection); Dailey v. City of Lawton, 425 F.2d 1037 (10th Cir. 1970) (denial of building permit and zoning change by planning commission and city council to construct low-mcome housing held racially motivated, arbitrary, and unreasonable); Anderson v. Town of Forest Park, 239 F. Supp. 576 (W.D. Okla. 1965) (voiding ordimances relating to such things as well depths found to be enacted for the sole purpose of excluding blacks).

82. 436 F.2d 108 (2d Cir. 1970), cert. denied, 401 U.S. 1010 (1971).

83. 318 F. Supp. 669, 695 (W.D.N.Y. 1970).

84. 436 F.2d 108 (2d Cir. 1970).

85. 334 U.S. 1 (1948). 
that tend to raise construction prices or bar apartments, even in jurisdictions where courts would have stricken similar provisions incorporated in local zoning codes.

A rule of exclusionary zoning that would permit low-income housing to be built anywhere regardless of zoning would probably be averted in new, expensive tract developinents; these developinents are usually well protected by private deed restrictions. Covenants are less frequent in older, more inodest areas, ${ }^{86}$ and where they once existed, they have often expired by their own terms or by changed conditions. ${ }^{87}$

The burden of such a rule would tend to fall on those who purchase houses near the center of a city since that is where pressure for scattered, cutrate, intensive development is often the greatest. Increasingly, these home purchasers are black. Blacks were more likely to be homeowners in 1970 than in 1960 in both the cities and the suburbs while the percentage of home ownership among whites remamed unchanged in the cities and declined slightly over the decade in the suburbs. ${ }^{88}$

The equities of center-city homeowners could well be threatened by higher density developinent intruding into formerly single-family zones. The few studies of the effect of racial migration on property values imply that values remain stable as long as there is heavy demand for middle-income housing in mixed neighborhoods and black entry is not followed by significantly increased densities. ${ }^{80}$ A pohicy permitting low-rent projects everywhere but in black or mixed areas-assuming such amehorative efforts could withstand fourteenth amendment challenge-would betray the hopes of an army of black contractors and tradesmen whose chances of securing contracts are considerably greater at construction sites in black neighborhoods. ${ }^{90}$ It would also preclude the construction of new subsidized housing in areas where a substantial number of minority people would elect to live even if housing opportunities were freely available everywhere. ${ }^{01}$

86. R. Babcock, The Zoning GaMe 28 (1966).

87. Judicial approaches to the doctrine of changed conditions vary. See generally G. LEFCOE, LAND DEVELOPMENT LAW 1217-35 (1966).

88. The available indicators suggest that these central city houses are indeed habitable and deserve protection. For black households, the percentage of such hoines equipped with coinplete plumbing facihities increased from 79 percent in 1960 to 95 percent in 1970. The comparable gain for white households was from 93 to 97 percent.

89. See, e.g., Downs, Book Review, 36 LaND Econ. 181 (1960).

90. The practical reasons for inore successful bidding by black contractors in black neighborhoods are apparent. In addition, Congress has provided that in the subsidy housing program, "to the greatest extent feasible opportunities for training and employment . . . be given to lower income persons residing in the area of such housing." Housing and Urban Development Act of 1968 \$ 3, 12 U.S.C. $\$ 1701$ (1970).

91. Among the few sophisticated explorations of this market is one prepared by 
Zoning should be administered to preserve viable residential neighborhoods in center cities without stifling the development of new low-rent housing. If the Supreme Court had regarded article XXXIV as a racist provision, most zoning laws would have been similarly vulnerable. This is because almost all land use controls have a tendency to raise the price of some housing, thereby impinging on the claims of the poor to suburban housing, and thus adversely affecting the imterests of minority people. The trouble with this chain of reasoning is precisely as Justice Black noted: all laws disadvantage some groups, sometime, in some degree. If federal courts are to enter the zoning game, principles need to be articulated that can differentiate between zoning as a subterfuge for racial exclusion and zoning laws that protect the reasonable aspirations of homeowners.

II

\section{Judicial Review Based on NonRacial DifFerential Impacts}

\section{A. Valtierra, Poverty as a Suspect Classification, and Zoning}

If article XXXIV were to be assailed for the classification it embodies, that classification would be one based on poverty or wealth, not directly on race. The California public housing referendum makes no explicit mention of race; it applies to all low-rent public housing, and not just those projects inhabited by blacks or Chicanos. A "low rent housing project" under the article is defined as any development of housing "for persons of low income" fimanced or assisted by state or federal government, and "persons of low income" are further described as "persons or families who lack the anount of income which is necessary . . . to enable them, without financial assistance, to live in decent, safe and sanitary dwellings, without overcrowding."92 Thus, to qualify for low-rent public housing a person must be poor. If Congress somehow changed the eligibility standards so that only wellto-do or moderate-imcome families could live in such housing, article XXXIV, by its carefully drawn definition, would exempt it.

Presented with article XXXIV's explicit use of poverty as a basis for classification, the Supreme Court had a number of potential ways to respond. It could have followed in the path of the Ninth Circuit, which in Southern Alameda Spanish Speaking Organization v. City of Union City ${ }^{93}$ had equated wealth with race by declaring that low-income families "usually-if not always-are members of minority

Gruen \& Gruen of San Francisco for the Miami Valley Regional Planning Commission, on file with the anthor.

92. CAL. CONST. art. XXXIV, \& 1. See note 1 supra.

93. 424 F.2d 291 (9th Cir. 1970). 
groups."94 Actually, the Ninth Circuit was in error on the facts; a majority of those people below the poverty line are white, ${ }^{96}$ and most blacks have incomes well above poverty levels. ${ }^{00}$ While whites enjoy higher incomes on the average, in recent years, and particularly among young couples in the North and West, the gap is closing. Life continues hard for the aged poor and for the welfare mother-black or white-but young black couples in the North and West earn 91 percent of what their white counterparts receive, up from 78 percent ten years ago. ${ }^{97}$ A rule assuming that poverty is synonymous with race would be mistaken in 1971 and will, hopefully, become ludicrous by the end of the next decade.

There is a now familiar line of cases that has been construed (misconstrued, really) as making suspect distinctions based on poverty-quite apart from whether blacks and the poor are to be regarded in law as a single category. In Harper $v$. Virginia Board of Elections, ${ }^{98}$ the Court invalidated Virginia's poll tax. Several grounds for the holding appear in the opimion; providing special protection for the poor is among them. In Griffin v. Illinois, ${ }^{99}$ the Court held that the right of appeal could not be demied an indigent criminal defendant solely because he could not afford to pay for a trial transcript. The zenith of an expansive equal protection review was probably reached, though, in Shapiro v. Thompson, ${ }^{100}$ the case that invalidated Connecticut's oneyear residency requirement for public welfare.

Responsible liberal analysts of the Court's opinions have observed that Griffin, Harper, and Shapiro were-and in fact ought to have been

94. Id. at 296.

95. According to the current population reports, $17,480,000$ of the $25,522,000$. Bureau of the Census, U.S. Dep'T of Commerce, P-60, No. 77, at 2. Some 8,042,000 are listed as black or other.

96. Id. at 4 .

97. Id. at 4,7. These figures do not indicate whether the total income of black couples is more likely to be the product of two wage-earners rather than one. However, there is no reason to assume the percentage of working wives among blacks would have changed proportionate to whites over the past ten years, so that even if the figures overstate the relative earning power, they probably show the trend toward parity fairly well. Also, if whites are more likely to be in school, the figures may overstate comparative black earnings. Once again, however, there is no reason to assume blacks enjoy less higher education than they did a decade ago. The opposite is probably true, making the trend even more encouraging.

98. 383 U.S. 663 (1966).

99. 351 U.S. 12 (1956).

100. 394 U.S. 618 (1969). Even in Shapiro a majority could not be rounded up for the expansive equal protection view, as shown by the other rationales that were invoked: the right to travel and "reasonablencss" headings. If Shapiro nonetheless marked the zenith of the theory, the retrenching ean be said to have begun with Dandridge v. Williams, 397 U.S. 471 (1970). 
-decided on other bases. ${ }^{101}$ Furthermore, a number of the Justices have taken pains to stress that the results in these cases were reached or could have been reached by resort to the usual "reasonableness" or rational basis test and that the rhetoric of "suspect classifications," although invoked, was superfluous. ${ }^{102}$ Thus, a most thoughtful brief attacking article XXXIV deemphasized the suspect classification contention and sought instead to show that article XXXIV was arbitrary, invidious, and lacking in any rational basis. ${ }^{103}$

Civil rights lawyers were watching Valtierra closely to see how the Court would respond to the aspect of the case that implicitly raised an equal protection argument not based on race, hoping that the Court would set itself firmly against any "discrimination against the poor." An expansion of the suspect classification doctrine beyond race has been thought especially important by those who would eliminate exclusionary zoning.

To be sure, there are zoning cases that reek of racial discrimination, and Lackawanna is but among the more recent of a series of such

101. E.g., Michelman, Foreword to The Supreme Court 1968 Term, 83 HARV. L. Rev. 7, 22-32 (1969).

102. See, e.g., Note, Exclusionary Zoning and Equal Protection, 84 HARv. L. Rev. $1645,1654-55$ (1971). In Gordon v. Lance, 403 U.S. 1 (1971) [discussed in note 137 infra] the Court characterized Harper as a case involving an unreasonable basis for establishing voter qualifications, just as race had been impermissibly imposed as a couditiou for redistricting in Gomillion v. Lightfoot, 364 U.S. 339 (1960), tax status had been improperly imposed as a conditiou for voting in Kramer v. Uniou Free School Dist., 395 U.S. 621 (1969), and military status had been an unreasonable basis in Carrington v. Rash, 380 U.S. 89 (1965).

This reading of Harper would have considerable significance for Serrano v. Priest, 5 Cal. 3d 584, 487 P.2d 1241, 96 Cal. Rptr. 601 (1971), in which the state supreme court invalidated present school finance arrangements. From one perspective, the California case called for a compelling justificatiou for the use of local property taxes in school finance solely because poor people were affected especially adversely. So interpreted, a program of subventions for the children of the poor might be a satisfactory legislative respouse. Short of that, any disproportiouate expenditure per pupil would constitute prima facie proof of discrimination against the poor. If equal expenditures failed to produce equal results, even this standard could be insufficieut.

Alternately, more in line with the Supreme Court's interpretation of Harper in Gordon, the case could be read as stating that there is no reasonable nexus between school expenditures and local property tax rolls. The state has committed itself to providing public education and, having done so, must arrange a rational basis for payment and dehivery of school services. The irrationality of the present system is shown by the great inequities among school districts that exist regardless of the willingness of residents to support schools. If a community has good ratables, it may enjoy low tax rates while yet supporting high per-pupil expenditures. Perhaps if a system of fuuding eqnalization were developed, and communities could elect to tax themselves above that minimal level, a defeusible rationale would exist for coutinuing some amount of local funding. See generally Coons \& Sugarman, Family Choice in Education, 59 CalIF. L. REV. 321 (1971).

103. That brief was submitted by the National Urban Coalition, an amicus submission that the Court refused to accept, acting under Rule 42 of the Supreme Court 
cases that can be traced back 80 years. However, the Torrance situation desribed in the opening paragraphs of this Article was a more typical zoning controversy. True, some who opposed OGO's 236 project did so primarily for fear of black migration: a few racist barbs were shouted from the audience during the hearings, and a number of those now resident in Torrance came from nearby Inglewood to escape an influx of lowerclass blacks from south central Los Angeles. Yet, if the motivating factors in Torrance were listed, racial bias would be near the bottom. One homeowners' association was opposed to the project primarily because a scheduled freeway would have to be rerouted through their homes mstead of over now-vacant lots on which the 236 and two conventionally financed apartments would be built. Too, the usual anxieties were expressed about school impaction, loss of open space, and traffic congestion. Resentment was voiced agamst the 236 program as just another publicly funded "welfare" giveaway, a protest that is perhaps exacerbated in Torrance, which has suffered froin defense cutbacks. Lately, the council voted to rezone the entire precinct for manufacturing use-to the apparent delight of the residents in the area and the consternation of the chamber of commerce and those landowners whose property values are expected to decline. ${ }^{104}$ If the zoning moratorium and subsequent rezoning in Torrance were to be challenged as invidious, the evidence of racial bias most courts would require could probably not have been produced.

Recent suits agamst the Department of Housing and Urban Development suggest that former standards of racial bias may not be controlling should white communities seek to bar federally assisted housing. In Gautreaux v. Romney, the Department was held potentially hable for civil rights violations because it funded the Chicago Housing Authority, which was systematically locating all public lousing in black neighborhoods. ${ }^{105}$ This denied black persons ehible for public lousing the opportunity of moving outside "areas of minority concentration." In Shannon $v$. Romney, the Department was faulted for funding a rent supplement project in a black neighborlıod in Philadelphia without first considering the potential impact of the location decision on patterns

rules. Among the organizations joining in the brief were: Alliance for Labor Action, AFL-CIO, Lawyers' Committee for Civil Rights Under Law, NAACP Spccial Contribution Fund, National Association of Building Manufacturers, National Association of Intergroup Relations Officers, National Housing Conference, National Tenants Rights Organization, National Urban League, Pacific Southwest Regional Council of National Association of Housing and Redevelopment Officials, and Rural Housing A1liance.

104. South Bay Daily Breeze, Apr. 26, 1971, at 29, col. 2. See also id., Oct. 13, 1971, at 1, col. 5 .

105. Gautreax v. Romney, No. 71-1073 (7th Cir., Sept. 10, 1971); Gautreaux v. Chicago Housing Authority, 362 F. Supp. 582 (N.D. Ill. 1967). 
of racial concentration. The case was remanded to give HUD a chance to develop and apply an "institutionalized" method for making such a determination. ${ }^{106}$ In the interim HUD has proposed new project and site selection criteria that strongly favor sites and projects that provide integrated housing opportunities. ${ }^{107}$ Shannon and Gautreaux indicate that, under HUD's duty to take "affirmative action" for fair housing under the 1968 Civil Rights Act, the Department is obliged to fund subsidized housing throughout the metropolitan region and that a failure to do so constitutes a pattern of discrimination. Derivatively, white communities that resist such housing even though it meets prevailing density and design requirements would also contribute to a pattern of discrimination by tending to confine the location of such housing exclusively or predominantly to areas of minority concentration.

To urge that all zoning with even the shightest tendency to raise prices or discourage housing for poor people be regarded as constitutionally suspect is a temptation best resisted. Almost every law could be said to disadvantage some segment of the community, by wealth. Property taxes are thought to fall disproportionately on the poor (unless attention is given to the ways tax monies are spent). ${ }^{108}$ Income taxes, the studies show, are paid mainly by the solid middle classes. Auto pollution control devices that cost about the same for every car regardless of its price may properly be assailed as regressive. Even water pollution control, whether paid from higher prices for goods or tax revenues, could be regarded as prejudicial to the poor since they are less prepared to spend money on anything but the basics-food, shelter, and clothing. State-supported education has usually been of greater benefit to upwardly mobile working and middle classes than to those ehigible to receive Aid For Dependent Children. Even the results of Ralph Nader's notable efforts tend to aid the highly literate who have the most to spend on cars, meat, and drugs.

Some of the difficulties that would ensue if zoning ordinances affecting low-or moderate-incoine housing were felled summarily can be seen by studying Southern Alameda Spanish Speaking Organization $v$. City of Union City. ${ }^{108}$ Plamtiff was an OEO-funded nonprofit community organization seeking to construct a 280 -unit 236 project. The necessary rezoning had been granted but was later repealed by a pub-

106. Shannon v. Romney, 436 F.2d 809 (3d Cir. 1970); Shannon v. Romney, Civil No. 69-197 (E.D. Pa., filed July 8, 1971).

107. 24 C.F.R. \$ 200, Docket No. 4-71-119 (1971). See generally Lefcoe, The Impact of Civil Rights Litigation on HUD Policy, - URBAN LAWYER - (Nov. 1971).

108. J. Jensen, Property Taxation IN the Untred States 78-83 (1931); R. Netzer, ECONOMics of the Property TAX 40-59 (1966); CAI. Assembly INTERIM Comm. on Revenue and TaXation, State and Local Tax Burdens in California (1964).

109. 424 F.2d 291 (9th Cir. 1970). 
licly initiated referendum. The Ninth Circuit refused to declare zoning referendums unconstitutional but observed that if Union City's zoning laws worked to deny low-income people decent housing, a good equal protection claim would have been presented. ${ }^{110}$ When the case was remanded for a trial court determination of whether Union City had in fact practiced exclusionary zoning, the district judge found that it had not. ${ }^{111}$

Among SASSO's chief opponents were residents of a neighboring modestly priced single-family tract. The inayor of Union City at the time the dispute arose was a Chicano who opposed the project, as did many of the residents in the neigliboring development, fully a quarter of whom, according to the then mayor, were of Mexican or Spanish descent. ${ }^{112}$ They claimed to be trying to bar a low-rent project of such huge proportions as would have altered the social class in their neighborhood. Assigning bad faith to them would be more than a little callous, since even the most stable of communities can absorb only a limited number of lower-inconie families without disrupting the life styles and property values of current middle-inconie residents. ${ }^{118}$

Subsequently, perhaps as a result of the court action, but possibly not, sites were rezoned for a privately developed public housing proj-

110. Id. at 295-96.

111. Southern Alameda Spanish Speaking Organization v. City of Union City, Civil No. 51590 (N.D. Cal., July 31, 1970).

112. Id.:

At the previous hearings in this case, held on July 3, 1969 and in Novelnber, 1969, plaintiffs, seeking at that time to invalidate the referendum election, contended that the real reason for invoking referendum proceedings was a racially motivated attempt on the part of the Anglo-American element of the population to exclude Mexican-Americans from the Baker Road vicinity.

The record then, as now, shows however, that the electorate of Union City has thus far elected a city government in which the City Council consists of two councilmen of Mexican-American descent, one of Portugese descent, one of Spamish descent and one of Japanese descent-but no Anglo-American; the City Planning Commission consists of other members of Puerto Rican descent and only two of Anglo-American descent; the Park and Recreation Commission consists of two members of Mexican-American descent, one of Portugese descent and only one of Anglo-American descent.

The record shows further that even in Westview Estates, from which opposition to the Baker Road rezoning came, the racial composition, although predominantly Anglo-American, has a significant $25 \%$ of Mexican-Americans along with $25 \%$ other minorities and $50 \%$ Anglo-American. The vote on the referendum, even in the predominantly Mexican-American Decoto and Alvarado precincts, was more or less evenly divided on the rezoning issue.

113. See Statement by A. Downs, Residential Segregation by Income and Race, to the Senate Select Cominittee on Equal Educational Opportunity, Washington, D.C., Sept. 1, 1970, at 2-6. See also Sell, Pomona Gropes for Stability in Storm of Ethnic Change, L.A. Times, Jan. 24, 1971, \& B, at 1, col. 4. Cf. Shannon v. Romney, 436 F.2d 809 (3d Cir. 1970) (the chief objectors seemed to have been middle-class blacks trying to keep low-rent housing from their neighborhood); El Cortez Heights Residents and Property Owners Ass'n v. Housing Authority, 10 Ariz. App. 132, 457 P.2d 294 (1969) (middle-income black objectors). 
ect, and Union City and SASSO reached a settlement that will permit the construction of 140 multifamily units on the site instead of the proposed 280 units. $^{114}$ Several sites were proposed for public housing projects, and those that did not border single-family zones had an easy time obtaining the necessary local approval. The site that does adjoin a single-family area will not be rezoned readily, if at all. All these later events support the claim originally made by the referendum proponents that ethnic or racial bias had not prompted their opposition. What they had opposed was the construction of apartment house units at high densities on a site adjoining a single-family tract. Rezoning was accomphished without tumult once the proposed multifamily density was lowered and provisions were made for some single houses on the site.

The Torrance and Union City situations indicate how much more ambiguous the facts are likely to be when economic exclusion is alleged instead of racial bias. In luxury villages-even those with highly exclusionary zoning laws-the cost of land is usually the main preventive of moderately priced housing. More typical suburbs, where housing has been constructed for people with nloderate incomes, may utilize land use controls that appear to be subterfuges for means tests yet have perfectly defensible alternate explanations for their zoning decisions. The special land use needs of such communities, possibly, receive too hittle judicial sympathy. Sometimes less affluent towns have tried to "upzone"- to increase lot sizes or reduce densities-in order to attract a broader economic or racial mix, perhaps with a view to lessening school impaction. In challenges by developers, courts have usually disapproved these efforts. In so doing, they may be making too indiscriminate an attack on all "exclusionary" ordinances.

\section{B. The Court's Treatment of the Disadvantageous Classification in Valtierra}

Confronted with the classification in article XXXIV the Court could have chosen to dismiss it as just another disadvantageous classification deserving no special scrutiny. Or the Court might have found that while ostensibly the article affected the poor, in reality other bases

114. A stipulation was entered between SASSO and Union City [Civil No. 51590 (N.D. Cal., filed May 21, 1971)]. In addition to providing that 140 units of 236 housing are to be allowed to be construoted on the Baker Road site, the city agreed to support SASSO's application for rent supplements for as many as 30\% of the units. The city further promised to apply for 200 units of public housing. Even before the stipulation was entered, the city had obtained from two large-scale private developers, Kaufman \& Broad and William Lyon Developnent Coinpany, a commitment to nuake 235 financing available to purchasers of up to $10 \%$ of the housing those companies build in Umion City. The stipulation pledges the city to use due diligence in encouraging these private developers to meet their commitmeuts to the city. 
existed for a public lousing referendum requirement or, alternately, that referendums are so common in California that the article cannot be said to single out anything in particular. Finally, the Court could have found that the classification, being disadvantageous, nnerited review, but only according to the extent of deprivation embodied in it.

Reasonable readers of Valtierra may certainly differ on which of these options the Court took. No explicit mention is made in the majority opinion of whether the Court perceived in article XXXIV a classification singling out a "discrete and insular minority" for special treatment-except for the Court's express rejection of the claim that the article affected racial minorities particularly. The Court might somehow have concluded that the article, though impinging a little on the interests of the poor, impinged so moderately as to justify no judicial scrutiny whatever. More likely, the Court's opinion was based on a determination that the article was reasonable even though it affected poor people specially. Otherwise, the Court should not have felt obliged to detail in this fashion the main supports it found for the article.

Wisely, it chose to ignore the appellant's contention that automatic referendums for public housing could be justified because this type of housmg had often been of mammoth size and institutional design. ${ }^{115}$ Instead, the reasonableness of the referendum was sustained simply because

115. These were poor props for article XXXIV. Present HUD regulations disfavor gigantic, spartan projects that would cluster poor families, impact local schools, and dominate residential streets. Furthermore, Congress has not exempted public housing from whatever architectural or design review process any locality elects to impose on new construction generally. No such exemptiou appears in the conventional public housing legislation, that is, United States Housing Act of $1937 \$ \S 1-22$, as amended, 42 U.S.C. $\$ \$ 1401-22$ (1970). In fact, local control provisions are quite prominant: for example, $\$ 15(7)$ (b), 42 U.S.C. $\$ 1415(7)$ (b) (1970) (local cooperation agreement requirement); Housing Act of $1949 \S 101(\mathrm{c})$, 42 U.S.C. $\$ 1451$ (c) (1970) (requiring a workable program). If cities are concerned about the appearance or design of pubkic housing, they ought to be equally worried about other forms of multifamily housing. Horrendous illustrations of conventionally financed projects are easy to find. The proper way to affect size or design is to create an orderly, equitable process of review. A community that fails to do so and instead seeks the right to turn down public housing projects because they lave sometimes in some places been of inferior quality is not merely overreacting. It is adopting a device so inappropriate for preventing the claimed prospective damage as to call its good faith into question. Small wonder the Court chose to step around appellant's "design" justification for article XXXIV.

The argument that public housing projects were often of mammoth size was equally ludicrous. High densities are used to apportion the high land costs of most center city sites. See Ledbetter, Public Housing-A Social Experiment Seeks Acceptance, 32 LaW \& Contemp. Prob. 490, 496 (1967). Cf. D. Netzer, Economics and Urann Problems 81-82 (1970). Public housing tends to be constructed in heavily populated areas not only because the greatest needs for new housing are concentrated there but because suburban communities exclude it. Referendum requirements are among the de- 
[t]his procedure ensures that all the people of a community will have a voice in a decision which may lead to large expenditures of local governmental funds for imcreased public services and to lower tax revenues. ${ }^{110}$

Yet, such costs can be derived from any number of sources. The Court attempted to clarify its meaning in footnote four:

Public low-rent housing projects are financed through bonds issued by the local lousing authority. To be sure, the Federal Government contracts to make contributions sufficient to cover interest and principal, but the local government body must agree to provide all mumipal services for the units and to waive all taxes on the property. The local services to be provided include schools, police, and fire protection, sewers, streets, drains, and lighting. Some of the cost is defrayed by the local governing body's receipt of $10 \%$ of the housing project rentals, but of course the rentals are set artificially low. Both appellants and appellees agree that the building of federally financed low-cost housing entails costs to the local community. ${ }^{117}$

This should not be taken to mean that the Court would allow a community to subject to public vote any proposed land development that threatens to cost more in mumicipal services than it yields in tax receipts. If tolerated, such an argument could serve to justify a stay on most residential construction. Indeed, there are places where only houses costing over $\$ 100,000$ pay their own way in taxes. ${ }^{118}$ If special hurdles may be imposed whenever development threatens the commumity fisc, the authority of Shapiro $v$. Thompson would also be weakened, for that opinion noted:

Appellant's reasoning [im trying to justify a one-year residency requirement for welfare entitlements] would logically permit the State to bar new residents from schools, parks, and libraries or deprive thein of police and fire protection. Indeed it would permit the State to apportion all benefits and services according to the past tax con-

vices used to keep public housing out of suburbs where land costs are lower and where, therefore, garden apartments and even single family houses can be built under the public honsing program.

116. 402 U.S. at 143.

117. Id. n.4.

118. See, e.g., Foothills Environmental Design Study, Final Report to the City of Palo Alto 4, Feb. 25, 1971; Greenhouse, Rise in Jobs Poses Problems in Suburbs, N.Y. Times, Aug. 18, 1971, at 1, col. 3. H.M. Franklin, Urban Growth Policy in the Courts, a paper delivered to the 1971 Nat'l Planning Conference, ASPO, New Orleans, March 30, 1971, describes a study soon to appear in Urban Land that concludes that to break even on a four-bedroom house, a single family houne would have to sell for $\$ 100,000$. "The more typical, lower-priced suburban tract development of this size selling for around $\$ 35,000$ would result in an annual tax deficit of about $\$ 1,500$ per unit." Id. at 16. These studies all assume that school costs will be met at least partly from local property taxes. 
tributions of its citizens. The Equal Protection Clause prohibits such an apportionment of state services. ${ }^{110}$

The one interpretation of Valtierra's footnote four that does not lead to troubling inconsistencies with existing property law and recent Supreme Court opinions is that the article's reasonableness was predicated only on the required waiver of property taxes. ${ }^{120}$ This reading makes sense since it is precisely the impact on property owners that justifies subjecting to an automatic referendum the issuance of general obligation bonds pledging the full faith and credit of the city. Since property taxes are the chief and most stable source of municipal revenue, property taxpayers usually bear the burden of general obligation bonds and are, at a minimum, contingently liable.

Yet, appellees pointed out that:

land privately devoted to school, church, museum, and hospital uses is tax exempt but owners are normally free to devote land to such uses-thereby depriving the community of that land's potentialwithout obtaining any specific permission, as long as the land is compatibly zoned. ${ }^{121}$

Indeed, one of the raging controversies in California property taxation law involves the exemption granted to churcli-sponsored homes for the aged. ${ }^{122}$ Some of these developments louse prosperous old folks in luxurious accommodations and are yet exempt solely because of church sponsorship. The mequity is obvious in exempting the well-to-do elderly without a public referendum vote and yet allowing the electorate to restrict a publicly sponsored lome for the aged poor solely because it yields only a portion-usually a third or so-of its property tax bill.

The Court's refusal to redress this inequity is perhaps a little less

119. 394 U.S. at 632-33.

120. 1 A. Rathkopf, The LaW of Zoning and Planning 214-15 (1970 cum. supp.). When the extent of the restriction is not all-encompassing, some courts have accepted tax-ratable considerations as a justification for zoning boundary determinations. See Gruber v. Mayor and Township Com. of Raritan Township, 39 N.J. 1, 186 A.2d 489 (1962); Kozesnik v. Montgomery Township, 24 N.J. 154, 131 A.2d 1 (1957). The extent of the land use restriction is what distinguishes these two New Jersey cases from SASSO v. City of Union City, 424 F.2d 291 (9th Cir. 1970), and the Pennsylvania cases discussed in text accompanying notes 165-68 infra. When use allocation, and not exclusion, is at issue, courts have accepted arguments urging the desirability of the segregated land use achieved through noncumulative zoning. See People ex rel. Skokie Town House Builders, Inc. v. Village of Morton Grove, 16 Ill.2d 183, 157 N.E.2d 33 (1959).

121. Brief for National Urbau Coalition as Amicus Curiae at 17-18, Janies v. Valtierra, 402 U.S. 137 (1971). The same point was made in appellee's brief at 7.

122. See Holbrook, Maxwell \& Rourke, Fifield Manor Tax Refund Cases, 35 S. CaL. L. Rev. 276 (1962), commenting on Fifield Manor v. County of Los Angeles, $188 \mathrm{Cal}$. App. 2d 1, 10 Cal. Rptr. 242 (2d Dist. 1961). 
objectionable because article XXXIV does not necessarily work to deny poor people in San Jose a chance at public loousing. The Court noted that the United Statcs Housing Act does not require local participation; states and cities are perfectly free to opt against creating the necessary apparatus for utilizing these programs. ${ }^{123}$ The California Legislature has enabled each county and city to form a housing authority, ${ }^{124}$ but not all local governments have elected to do so. ${ }^{125}$ The City of San Jose, however, has. Thus, we are not presented with the case in whicls a locality througli inaction deprives its poor of all access to a form of federal assistance. In fact, the San Jose Housing Authority has been instrumental in the developinent of about as many units of public lousing for its poor as other cities of comparable size in states where there are no public housing referendums. ${ }^{126}$ Although without a referendum, conventional public housing cannot be constructed, there are other housing programs that serve the poor. ${ }^{127}$ HUD, in apportioning subsidy commitunents, could allow San Jose to utilize through these other programs whatever it was unable to use due to article XXXIV. ${ }^{128}$

Despite all appearances, article XXXIV may actually encourage the production of low-income units. For instance, Califorma is the

123. 402 U.S. at 140.

124. Cal. Health \& Safety Code $\S 34240$ (West 1967).

125. The City of San Jose did not form a housing authority until 1966; for the entire country, San Diego was the last city with a population greater than 250,000 people to form a housing authority. See NAT'L INsTrTute FOR EDUc. IN LAW AND POVERTY, HANDBOOK on Housing LAw, ch. IV, pt. I, at 4; Cal. Dep't of Housing and Community Developinent, Roster of Housing Authorities and Redevelopinent Agencies in California, April 1971.

126. The population of San Jose is 445,779 and the city's public housing consists of approximately 1,490 units leased in existing housing under the Housing Act of 1937 $\S 23$, as amended, Housing and Urban Development Act of $1965 \S 103(\mathrm{a}), 42$ U.S.C. $\S 1421$ (b) (1970).

\begin{tabular}{|c|c|c|c|}
\hline & $\begin{array}{l}\text { Public Housing } \\
\text { Ulnits Per } \\
100 \text { Persons }\end{array}$ & Population & $\begin{array}{c}\text { Approximate Number } \\
\text { of Public } \\
\text { Housing Units }\end{array}$ \\
\hline San Jose & 33 & 445,779 & $\begin{array}{c}1,490 \\
\text { (all \& } 23 \text { leased units) }\end{array}$ \\
\hline $\begin{array}{l}\text { Albuquerque } \\
\text { Kansas City, Mo. }\end{array}$ & $\begin{array}{c}31 \\
52\end{array}$ & $\begin{array}{r}243,741 \\
507,087\end{array}$ & $\begin{array}{c}760 \\
2,626\end{array}$ \\
\hline
\end{tabular}

Population data from 1970 Census Advance Sheets, obtained in teleplone conversation with staff of U.S. Ceusus Bureau, Los Angeles office, Aug. 3, 1971. Public housing data obtained in telephone conversations, Aug. 5, 1971, from HUD offices in San Francisco, Albuquerque, and Kansas City, Missouri.

127. E.g., United States Housing Act of $1937 \S 23$, as amended, Housing and Urban Development Act of 1965 \$ $103(\mathrm{a}), 42$ U.S.C. $\$ 1421(\mathrm{~b})$ (1970) (leased housing program); 42 U.S.C. $\$ 1421$ (b) (1970) (turnkey I); 42 U.S.C. $\$ 1421$ (b)(a)(3) (1970) (turnkey leasing); 12 U.S.C. $\$ 1701$ (1970) (rent supplement program).

A description and appraisal of all the federal programs appears in R. TAGGERT, Low-INCOME Housing: A CRITIQUE OF Federal AID (1970).

128. The Region IX HUD office presently does not administer the various public housing programs in a manner that allows San Jose to redeem the lost conventional 
leading user of public lousing funds for turnkey leasing projects because such projects are thought not subject to article XXXIV. ${ }^{120}$ These are privately built units that developers construct according to general plans prescribed by local housing authorities. The private developer locates and negotiates for the site. Although he does not have the right to exercise eminent domain power, as would a housing authority, he is free to deal more sharply for land and need not disclose the use to which it is to be put $\mathrm{m}$ order to have it rezoned for multifamily use. The builder is responsible for obtaining his own construction loan and permanent financing. On completion, the project is leased to the housing authority at a predetermined rent for possibly as long as 20 years. The authority then subleases individual apartments to the same people who would have been eligible for conventional public liousing. The master lease, guaranteed by the federal government, provides the security on which most project lenders rely.

This program has a number of advantages over conventional public housing. Turnkey projects tend to be smaller and are usually indistimguishable from local garden apartments. They have, therefore, engendered far less local political opposition. Private devclopment assures more rapid construction; the builder is goaded into prompt construction by the simple fact that lie lias to bear construction loan costs and can only pass them on to the extent that they are incorporated in his lease price. The lease price, in turn, is reached by negotiation with the housing authority, which takes into account the amount these apartments should cost to build, including the construction loan interest that should accrue in the normal construction period. If a builder finishes earlier than contemplated, so that he has paid a lesser cumulative amount of interest on construction financing, le pockets the housing authority's lease payments undiminished. If he is slow, the lease payments do not go up, and the day he first receives cash from the housing authority is delayed. Rapid construction lias obvious and

units through other programs that avoid the referendum requirement. Telephone interview with Harvey Kroll, economist for Region IX, Dep't of Housing and Urban Development, Aug. 3, 1971. However, Mr. Kroll agrees that a redemption policy is possible since the public housing legislation provides an authorization sufficiently broad to permit a trade of the units allocated for an area from one public housing program to another. Id. The only limitation on the allocation of new annual contributions contracts by public loousing program appears in the Housing and Urban Development Act of 1970 . The 1970 Act requires that $30 \%$ of new annual contributions authority go for leased units. An official in the central HUD office also points out that HUD follows a "fair share" distribution policy based on the number of families eligible for public housing in a given area. As a result of the Valtierra problem, he said, HUD will lean toward a higher leasing alloeation for California. Id., Aug. 4, 1971.

129. See text accompanying notes 224-28 infra. 
special advantages when housing is needed quickly, as for renewal relocatees or to alleviate existing shortages.

On the debit side, turnkey leasing does impose a relatively heavier burden on housing authority funds. Property taxes have to be paid without abatement since the project is privately owned. And lease payments must be large enough to amortize a conventional mortgage at regular market rates. In contrast, conventional public housing is ordinarily funded through state-issued, federally guaranteed bonds. The federal guarantee assures them a prime rate in the bond market, and the fact of issuance by an instrumentality of state government entitles the bondholder to an exemption of the interest from federal taxation.

These savings are illusory, however, as can be seen by shifting the focus from the special funds appropriated for the production of public housing to the public fisc as a whole. Property taxes not levied are absorbed by the host communities-disproportionately the largest cities, which have more than a fair share of the poor. The same pohicy of joint federal and local responsibility for the poor that supports revenue sharing and the federal underwriting of welfare payments speaks clearly for withdrawing the property tax exemption from public housing. Congress has before it this session a bill that would remove the property tax exemption from public housing. ${ }^{130}$ Although mortgage payments at conventional rates may be twice as high as imterest on tax-exempt, government-guaranteed bonds, replacing the private financing of turnkey leasing with such bonds would be of uncertain value, because any bond the federal government issues tends to raise the cost of all government borrowing by increasing the supply of bonds on the market. ${ }^{131}$ Too, the federal income tax exemption provided for the interest paid on these bonds is sought primarily by those in the highest tax brackets. In toto, this form of subsidy is probably more expensive per unit of housing realized than a direct subsidy.

Thus, it can be argued that article XXXIV only shifts the form of public housing. In Valtierra, it was never shown whether total production had actually been enhanced or diminished by the referendum requirement. The involveinent of private developers and conventional lenders and the payment of a full property tax make turnkey leasing pohitically inore acceptable than conventional public housmg. Con-

130. The Housing and Urban Development Act of 1971, H.R. 9688, 92d Cong., 1st Sess., 117 CoNG. REc. 7253 (1971).

131. Public housing bonds are presently paying 5\%. A private developer in California, to finance a project of comparable cost, will pay up to $83 / 4 \%$ plns two points on his pernanent financing and up to $5 \%$ plus five points on his construction loan. Telephone conversation, Aug. 2, 1971, with Philip Rask, Acting Program Manager, Dep't of Housing and Urban Development, Los Angeles Area Office. 
gressional enthusiasm has been manifest in generous funding for public housing in recent years. ${ }^{132}$ In what respect, then, are poor people disadvantaged by a referendum requirement that compels resort to turnkey leasing and discourages conventional public housing?

Although appellant did not make a direct comparison of the merits of turnkey leasing to conventional public housing, it did take pains to show that many housing programs for persons of low and moderate income were available beyond the reach of article XXXIV. ${ }^{133} \mathrm{Al}-$ though the Valtierra opinion is silent on this question, it is reasonable to surmise, as the next section of this Article tries to show, that the Court's willingness to accept the fiscal justification for article XXXIV rather uncritically might be due largely to a perception that appellees' important interests were but shightly affected.

\section{III}

\section{TOWARd Standards For Judicial Review of Exclustonary ZONING}

\section{A. The Supreme Court's Flexible and Selective Reasonableness Standard}

It has been tempting to perceive the Court as working with an all-or-none rule in such cases as Griffin, Harper, Shapiro, Dandridge, and now Valtierra. Expedience often underwrites the translation of complex judicial statements into rough-and-ready rules for decision. How siniple it would be if only heroic explanations could save laws jeopardizing one of a definitive hist of fundamental rights or creating certain specified suspect classifications. All other classifications would be subject to the ordinary pohitical process unless no reasonable justification could be conceived ${ }^{134}$ or, alternatively, unless the classification were adjudged unreasonable despite the rationalizations inventive judicial minds could have conjured. ${ }^{135}$

In fact, the Court's behavior has been more complex than this two-dimensional perspective implies. Some questionable classifications have been dealt the lenient "any conceivable basis" review. ${ }^{130}$ Others,

132. Funds for public housing are not earmarked for individual public housing programs-for example, conventional, turnkey, turnkey leasing, and $\S 23$ leasing. However, Congressional interest in the leasing programs is clearly revealed in 1970 Housing and Urban Developinent Act $\$ 203,42$ U.S.C. $\$ 1410$ (1970), which requires that 30 percent of new annual contributions authority go for leased units. And general funding levels have beeu increased substantially since 1968.

133. Brief for Appellant at 19-21, James v. Valtierra, 402 U.S. 137 (1971).

134. See Dandridge v. Williams, 397 U.S. 471 (1970).

135. Id. at 489 (Harlan, J., concurring).

136. See McGowan v. Maryland, 366 U.S. 420 (1961) (Sunday closing law); Lindsley v. Natural Carbonic Gas Co., 220 U.S. 61 (1910). 
though ultimately sustained, were treated to a longer exposition outlining what there was about them that merited being called reasonable. ${ }^{137}$ Yet other classifications have been stricken as patently unreasonable. ${ }^{138}$ Thus, a few opinions have been issued lately that show the Court utilizing a sort of cost-benefit framework, albeit one specially adapted to the demands placed on an institution whose ultimate goal is not efficiency, but justice. Valtierra is among them. Certain aspects emerge from these cases as determinants of the scope of review rendered.

\section{The Extent of Harm}

Following the de minimus naxim, some cases seem to have conditioned review on the extent of harm. Article XXXIV was sustained partly for the alleged fiscal impact public housing might have in host communities. Yet the Court has not always been so solicitous of fiscal arguments. This past term, in Boddie v. Connecticut, ${ }^{139}$ it held that indigent persons could not be denied a divorce for want of the requisite filing fees. There are, of course, inany points of dissimilarity between Boddie and Valtierra. For example, Boddie involved a procedural due process claim to the right to a divorce (or remarriage), and by requiring all who sought inarriage termination to go through the process, the state's fee effectively barred indigents from access. Perhaps if the state were as deeply responsible for access to housing as it is for access to divorces, a process that subjects poor people to a public vote as a condition to entry might also fail on due process grounds. But in fact the state is not so mvolved. Public housing accounts for only a fraction-one percent or so-of the nation's housing stock, and fewer

137. E.g., Dandridge v. Williams, 397 U.S. 471 (1970). In Gordon v. Lance, 403 U.S. 1 (1971), the Court sustained West Virginia's constitutional and statutory requirements that bonded indebtedness be incurred only with the approval of $60 \%$ of the votters in a referendum electiou. In Cipriano v. City of Houma, 395 U.S. 701 (1969), the Court had leld impermissible the limitation to "property taxpayers" of the right to vote in a revenue bond referendum. Contrasting the cases, the Court observed that "Cipriano was no inore than a reassertion of the principle, consistently recognized, that an individual inay not be denied access to the ballot because of some extraneous condition, such as race." Gordon v. Lance, supra at 5 . In other words, the condition was utterly unreasonable. To justify the West Virginia $60 \%$ vote requirennent, the Court noted that the Federal Constitution itself provides occasions when a simple majority vote is insufficient, and that in "voting to issue bonds voters are committing, in part, the credit of infants and of generations yet unborn, and some restriction on such commitment is not an unreasonable demand." Id. at 6.

138. Cipriano v. City of Houma, 395 U.S. 701, 707 (1968) (Black, Stewart, J.J., concurring) (provision that only property taxpayers are eligible to vote in election concerning revenue bonds of municipal utility system); Slapiro v. Thompson, 394 U.S. 618 (1969) (one-year residency requirement as condition to receiving welfare assistance).

139. 401 U.S. 371 (1971). 


\section{than ten percent of the people classified as in poverty occupy publicly owned units. ${ }^{140}$}

140. There are approximately 2.5 million public housing tenants. See HUD, Justifications for 1971 Estimates, Renewal and Housing Assistance Programs, at E-19 (1970), prepared for the Committee on Appropriations, House of Representatives. Approximately 25.5 milhion Americans are classified as poor. See L.A. Times, May 8, 1971 , $\$ 1$, at 1, col. 3. The Los Angeles Times statistics were taken from a U.S. Census Bureau study comparing poverty trends in the 1960's to poventy trends in the 1970's. Eligibility for public housing is not coterminous with federal definitions of poverty. It is determined locally, and cities have strong financial incentives for favoring as properous a tenantry as federal limitations will allow. The upshot is that possibly $40 \%$ of all units are occupied by people whose mcoines are above federal poverty levels, with only about $6 \%$ of the poor residing in public housing.

Another example of the Court's treatment of extent is provided by three recent welfare cases. In Dandridge v. Williams, 397 U.S. (1970), Maryland's AFDC formula was challenged for pegging the ceiling for payments at the allotment for a family of five. Those who objected to the formula tried to suggest that all children after the cutoff point were receiving nothing. But as Justice Stewart noted, "The practical effect of the Maryland regulation is that all children, even in very large families do receive some aid." Id. at 481 . Under the Maryland formula a ceiling was placed at $\$ 250$ a month in certain counties and Baltimore City and $\$ 240$ elsewhere. The extent of deprivation entailed was inferentially described when the Court noted that, "[B]y keying the maximum family AFDC grants to the minimum wage a steadily einployed head of a household receives, the State maintains some seinblance of an equitable balance between families on welfare and those supported by an employed breadwinner." In the footnote to this statement, the Court printed the federal and Maryland minimum wages. They turn out to be a shade lower than the Maryland welfare ceiling. If large families on welfare are deprived in Maryland, they are no worse off than those who earn only the prescribed minimum wage. Id. at 486.

Justice Stewart described at length the arguments supporting the Maryland formula, and Justice Marshall, in dissent, responded point by point. Their disagreement, though, was probably not in differing assessments of the strength of the Maryland defense but in how strong a defense they each thought to have been necessary. Justice Stewart had quoted McGowan v. Maryland, 366 U.S. 430 (1961): "A statutory discrimination will not be set aside if any state of facts reasonably may be conceived to justify it." 397 U.S. at 485 . Justice Marshall observed that, previously, such a loose standard had been deemed appropriate only in cases concerning the regulation of business interests; he was dismayed to see it applied by the majority in a case involving social welfare. Id. at 520.

Why had the court adopted a less rigorous test than was applied in Goldberg v. Kelly, 397 U.S. 254 (1970), and Shapiro v. Thompson, 394 U.S. 618 (1969)? Kelly had been summarily removed from the welfare rolls without notice or hearing; Thompson was being demied welfare payinents until he could satisfy Connecticut's one-year residency requirement. Thus, both cases can be perceived as affecting interests of a kind the Court has traditionally safeguarded; procedural fairness in Goldberg, travel in Shapiro. The cases may also be contrasted in another way: being denied welfare is a greater injury than being forced to get by on an inadequate sum. Yet, had Maryland elected to draw the AFDC ceiling at the allotment for a family of two, presumably the Court would have looked more closely at the state's rationale. This was nearly acknowledged by the majority: "The problems of government are practical ones and may justify if they do not require, rough accommodations-illogical, it may be, and unscientific." Dandridge v. Willians, 397 U.S. at 485, quoting Metropolis Theater Co. v. City of Chicago, 228 U.S. 61, 69-70 (1913). Dandridge did not involve a different kind of right than was present in Goldberg and Shapiro. All three cases present claims against 


\section{The Kind of Interests Affected}

Another determinant of review is the kind of interest implicated. Boddie shows that a rigorous review is not reserved solely for those cases involving race or for those involving rights enumerated in the Constitution. Palmer $v$. Thompson, the Jackson swimming pool case, indicates a further matter of importance in court discussions under this heading. Although racial classifications, when perceived, continue to occupy a specially suspect place, the closing of a public facility, as in Palmer, can be characterized either as tantamount to racial exclusion or as a fiscal decision. The kind of interest at issue may have bearing on the Court's propensity to characterize a close case as involving a racial classification.

What if, instead of closing municipal pools, Jackson had responded to a school desegregation order with an attempt to shut down its public schools? Justice Blackınun implied his answer:

The pools are not part of the City's educational system. They are a general municipal service of the nice-to-have but not essential variety, and they are a service, perhaps a luxury, not enjoyed by many communities. ${ }^{141}$

This can be construed as a statement that in a case arguably entailing racial exclusion, the kind of facility involved will determine Justice Blackmun's willingness to resolve the dispute by calling it a race case. Put this way, his views amounts to little more than an endorsement of Griffin v. Prince Edward County. ${ }^{142}$ Justice Blackmun could also be interpreted as promising that the closing of a key public facility would occasion closer judicial scrutiny under the fourteenth amendment, racism aside. Some of the rigidity that seemed to accompany the Warren Court's use of equal protection may be traced back to the stormy days when the Court abandoned the cudgel of economic due process.

The opinion in Skinner v. Oklahoma ex rel. Williamson ${ }^{143}$ by Justice Douglas, which was written just as the Court was rejecting the use of due process as a basis for appraising the legitimacy of state laws, presaged the course of equal protection law:

welfare classification systems. Among the ways in which they may be distinguished is the extent to which a legitimate interest has been impaired. Even if Shapiro is taken as a travel (or, more functionally, a right to mobility) case, the question must be asked why the Court chose not to characterize Dandridge in the same way. Presumably, if Maryland uses a less favorable basis for compensating large families than is used in other states, people with large families will be deterred from migrating to Maryland. The choice of characterizations depends soinewhat on the extent to which the protected interest is affected.

141. 403 U.S. at 299.

142. 377 U.S. 218 (1964).

143. 316 U.S. 535 (1942). 
We are dealing here with legislation which involves one of the basic civil rights of man. Marriage and procreation are fundanental to the very existence and survival of the race. The power to sterilize, if exercised, may have subtle, far-reaching and devastating effects. In evil or reckless hands it can cause races or types which are imimical to the dominant group to wither and disappear. There is no redemption for the individual whom the law touches. Any experiment which the State conducts is to his irreparable injury. He is forever deprived of a basic liberty. We mention these matters not to reexamine the scope of the police power of the States. We advert to thein merely in emphasis of our view that strict scrutiny of the classification which a State makes in a sterilization law is essential, lest unwittingly, or otherwise, invidious discriminations are made against groups or types of individuals in violation of the constitutional guaranty of just and equal laws. ${ }^{144}$

This passage may be read as potentially limiting the interests to be afforded judicial protection, because Skinner implies that unless an interest is so characterized, the classification it embodies-however senseless-will be free from scrutiny. Perhaps this all-or-none cliaracteristic of the "fundamental rights" doctrine, which traces from Skinner, can be attributed to the majority's reluctance to have the Court embark once again on an uncharted excursion on state law territory. Taken at face value, the "fundamental interest" language was most unpersuasive. Justice Douglas' opimion is inemorable for its graphic comparison of the chicken thief who could be sterilized under the act and the clicken embezzler whom the statute exempted. Could the former be imprisoned for up to 30 years if a small fine were the maximum penalty for the latter? No reassurance was provided by the statement in the majority opinion that "if we liad here only a question as to a Statc's classification of crimes, such as embezzlement or larceny, no substantial federal question would be raised." 45 It seems only whimsical to contend that while sterilization threatens a "fundamental right," imprisonment does not.

There were several ways to have reached the same result short of declaring a fundamental right at stake and using this declaration to justify a close scrutiny of the Oklahoina law's patently arbitrary provisions. Alternate theories were suggested by the inajority:

It is urged that the Act cannot be sustained as an exercise of the police power, in view of the state of scientific authorities respecting inheritability of criminal traits. It is argued that due process is lacking because, under this Act, unlike the Act upheld in Buck v. Bell, 274 U.S. 200, the defendant is given no opportunity to be heard on the issue as to whether he is the probable potential parent of socially

144. Id. at 541 .

145. $1 d$. at 543. 
undesirable offspring. It is also suggested that the Act is penal in character and that the sterilization provided for is cruel and unusual punishment and violative of the Fourteenth Amendment. We pass those points without intimating an opinion on them, for there is a feature of the Act which clearly condemns it. That is, its failure to meet the requirements of the equal protection clause of the Fourteenth Amendment. 140

Thus Skinner could have been decided on a broader and potentially more flexible basis. Justice Stone, concurring, opted for a due process analysis ${ }^{147}$ and Justice Jackson, also concurring separately, saw merit in both the equal protection and due process theories. ${ }^{148}$ But Justice Stone was among the minority who had been accused of abusing whatever license the due process clause might have given the Court. By the time of Skinner, Justice Stone's colleagues were probably wary of endorsing any potentially expansive premise for judical review.

We have at least one hint that a majority of the present Court would now prefer a more flexible approach than that afforded by the fundamental rights mechanism. Boddie, the divorce case, was carefully premised on due process. Justice Douglas protested, just as he would have, presumably, had a majority of his brethren joined with Justice Stone in 1941. Arguing for an equal protection analysis, he opposed a doctrinal framework that would free the Court to assess, case by case, whether the kind of interest affected seemed to merit a close judicial review:

Whatever residual element of substantive law the Due Process Clause may still have, it essentially regulates procedure. The Court today puts "flesh" upon the Due Process Clause by concluding that marriage and its dissolution are so important that an unhappy couple who are indigent should have access to the divorce courts free of charge. Fishing may be equally important to some communities. May an indigent be excused if he does not obtain a ticense which requires payment of money that he does not have . . . ?

The reach of the Equal Protection Clause is not definable with mathematical precision. But in spite of doubts by some, as it has been construed, rather definite guidelines have been developed: race is one; alienage is another; religion is another; poverty is still another; and class or caste yet another. ${ }^{149}$

A court that made everything depend on the nature of the classification-whether race, poverty, religion, class, or caste-could

146. Id. at 541 .

147. Id. at 545 .

148. Id.

149. Boddie v. Connecticut, 401 U.S. 371, $384-85$ (1971) (Douglas, J., concurring) (citations and footnote omitted). 
be expected to resist entering new fields, such as zoning, where so much of the court's energy would be spent deciding whether the suspect classification was in fact the one that prompted the particular zoning practice at issue. Similarly, if the analysis depended entirely on the depiction of housing as a fundamental interest, the court would be committed to an impossible task. Seldom are zoning laws drawn explicitly to effect racial or class distinctions, and every zoning law may bear indirectly on the price of housing. A court prepared to move from an equal protection to a due process framework would be able to gear its review to the qualitative aspects of particular zoning practices without condemning all local practices that in any way disadvantage the poor or affect housing. Concomitantly, such a court would not be obliged to reserve its powers for only those zoning practices that injure poor people. An approach analogous to that of Justices Stone and Jackson in Skinner-whether based on equal protection or due process-leaves ample opportunity for local governinents to retain a necessary operative role in the design and implementation of land use controls.

\section{Form}

There can be little doubt that had article XXXIV applied explicitly to those public housing projects scheduled for black occupancy, it would have been stricken. A specially protected interest would then have been threatened, and in a clearly discernible form. Similarly, had the article applied to all low-income housing programs, not only would the potential deprivation have been greater, but the article would arguably have been a means or incoine test for entry, the sort of law the Supreme Court struck down in the Grapes of Wrath case, Edwards $v$. California. ${ }^{150}$ The Valtierra Court would presuniably have responded differently to an automatic referendum on all housing, however financed and taxed, for poor people; form alone would call for the most stringent judicial inspection.

\section{Uniqueness}

Taking the Court at its word, the Valtierra decision was supportable because referendums apply commonly in California to many types of tax-exempt development besides public housing. Earhier, I argued that a state enacting a referendum requirement just for public housing would have difficulty sustaining it. ${ }^{151}$ If this is true, the umiqueness of a classification can be listed among the determining aspects of judicial scrutiny.

150. 314 U.S. 160 (1941).

151. See text accompanying note 57 supra. 


\section{B. Evolving Principles in Exclusionary Zoning Cases}

\section{Extent of Harm}

Perhaps the most visible symbol of exclusionary zoning is the minimum residential lot size requirement of an acre or more. Such minimums are associated with expensive suburbs and can raise housing costs where they are so extensive as to reduce sharply the number of smaller lots available for development, thereby affecting land prices. ${ }^{152}$ Although such overzoning for large lots is not uncommonparticularly in the mid-Atlantic states- ${ }^{153}$ harm can be averted by down-zoning surprisingly modest percentages of vacant land. ${ }^{154}$ Largelot zoning has less of an impact on the price of large lots than might be supposed; available studies suggest that large lots do not sell at proportionately greater prices than smaller ones. ${ }^{155}$ Rarely will people pay twice as much for a two-acre homesite as for one acre. Furthermore, the multiple acreage minimums-usually found in sylvan, luxury areas-are often accompanied by less exacting subdivision improvement requirements than are demanded of sites scheduled for more intensive use. Indeed, development costs may be so much cheaper as to offset the somewhat higher price of the large minimum lot. ${ }^{156}$

When a substantial portion of a rapidly developing region is set for acreage zoning, especially if coupled with elegant subdivision improvement requirements, the result may be highly exclusionary. In-

152. Among the very few studies mapping the extent of various exclusionary devices, including large-lot zoning, are those conducted by Professor Norman Williams of Rutgers University. Some of his findings appear in Williams \& Norman, Exclusionary Land Use Controls: The Case of Northeastern New Jersey, 22 SYracuse L. REv. 475, 497 (1971).

153. See id. at 639-42; American Society of Planning Officials, New Directions in Connecticut Planning Legislation 197 (Table 8) (1967) [hereafter cited as ASPO Connecticut Study]; Fels Institute of State and Local Government, University of Pennsylvania, Planning Measures and Controls in Southeastern Pennsylvania (1960).

154. If only 10 per cent of the land now zoned for a minimum lot size of 20,000 square feet or more were changed to permit 5,000-square-foot lots, and another 10 per cent of the 20,000-square-foot-and-over land were zoned to permit medium-low-density apartments (ten units per acre), just that land under the new density regulations would house $7,000,000$ additional persons. Reducing the two percentages of change to a little less than 3 per cent each would still allow the present population of the State to be doubled using only the rezoned land.

ASPO Connecticut Study at 189.

155. Coke \& Liebman, Political Values and Population Density Control, 37 LAND

Econ. 347, 356 (1961); Note, Large Lot Zoning, 78 YALE L.J. 1418, 1425 (1969).

156. In many communities, more expensive subdivision improvements are required in more intensive subdivisions, frequently starting somewhere in the range froin a half acre to an acre. If such requirements are imposed, the result may even be that, as developed land, smaller lots are actually more expensive than larger lots.

Williams \& Norman, supra note 152 , at 496. 
terestingly enough, most of the state courts that have confronted large-lot zoning take this into account. Such zones are upheld when their impacts on housing prices are negligible; they are usually stricken when zoning seems likely to affect the availability and price of houses.

The Virginia supreine court was among the first to apply a more rigorous standard of review for zoning that would have had extensive market-frustrating and economically segregating results. ${ }^{157} \mathrm{~A}$ two-acre minimuin lot size was placed on the entire western two-thirds of Fairfax County, Virginia, at that time the fastest growing county in the United States. After evaluating conflicting evidence, the trial judge concluded that the two-acre zoning had a permissible object: "to channel the county's population into the eastern one-third of the county where the cost of operating the government would be more economical." Although the Virgina supreme court accepted the trial court's findings of fact, it reversed, noting that utilites could be provided for the western part of the county, that "land values in the eastern area had increased while there was practically no market for purchase of land in the western area" after the restrictive zoning became effective, ${ }^{169}$ and, finally, that "the practical effect" of the law was "to prevent people in the low income bracket froin living in the western area, thereby reserving the western area for those who could afford to build houses on two acres or more." 160

Its extensive effects distinguish the Fairfax pattern from acceptable zoning laws. Thus, the Connecticut supreine court sustained a four-acre minimum lot size for New Canaan in 1959, noting that "as of the 1950 census, the town of New Canaan had the highest per capita income of any town, village or city in the United States." 101 Thus there was evidence of ainple deinand for large lots. Moreover, the population of the town was 16,000 at the time and had over 1,000 sites zoned for a half-acre or less. Similarly, a Maryland court sustained a five-acre minimum for a prime residential waterfront area in Queen Anne's County, observing that only 6.7 percent of the county had been reserved for large-lot development, the growth rate of the county was considerably lower than for the state, ample space had been reserved for all types of developinent including moderately priced houses, and the site in question was distinguishable from other tracts

157. See Carper v. Board of County Supervisors of Fairfax County, 200 Va. 653, 107 S.E.2d 390 (1959).

158. Id. at 660,107 S.E.2d at 395 .

159. Id.

160. Id. at 660,107 S.E.2d at 396.

161. Senior v. Zoning Comm'n of Town of New Canaan, 146 Conn. 531, 535, 153 A.2d 415, 417 (1959). 
"as a property almost in one class by itself, equal to or above any in charm or elegance."162

The Pennsylvania supreme court has, in a number of landmark cases, articulated a principled objection to any zoning "that has an exclusionary purpose or result." ${ }^{\text {163 }}$ The total exclusion of apartments and other uses from vast, developing areas has been held "completely unreasonable absent some extraordinary justification."164 The Pennsylvania court has no aversion to large lots or to luxurious residential districts without apartments, but it has recognized that certain land use practices enbody no planning justification at all save exclusion. In form, large lot sizes or the separation of single from multifamily housing may be irreproachable, but on a wholesale basis they exceed the zoning authority delegated to cities by the state. State enabling laws provide authority to regulate uses, densities, and sometimes design. They delegate to local commumities the right to zone out in-

162. County Comm'rs of Queen Anne's County v. Miles, 246 Md. 355, 361, 228 A.2d 450,452 (1967).

163. Concord Township Appeal, 439 Pa. 466, 268 A.2d 765 (1970); Exton Quarries, Inc. v. Zoning Bd. of Adjustment, $425 \mathrm{~Pa}$. 43, 58, 228 A.2d 169, 179 (1967); National Land and Inv. Co. v. Easttown Township Bd. of Adjustment, $419 \mathrm{~Pa}$. 504, 215 A.2d 597 (1965). See generally Sager, Tight Little Islands: Exclusionary Zoning, Equal Protection, and the Indigent, 21 Stan. L. REv. 767 (1969).

The Pennsylvania Court can be seen as applying a less-restrictive-alternative principle, much as Justice Keating did in Udell v. Haas:

Where, however local officials adopt a zoning amendment to deal with various problems that have arisen, but give no consideration to alternatives which might minimize the adverse effects of a change on particular landowners, and then call in the experts to justify the steps already taken in contemplation of anticipated litigation, closer judicial scrutiny is required to determine whether the amendment conforins to the comprehensive plan.

21 N.Y.2d at 470, 235 N.E.2d at 901, 288 N.Y.S.2d at 894-95 (emphasis added). See generally G.M. Struve, The Less-Restrictive-Alternative Principle and Economic Due Process, 80 HARv. L. Rev. 1463 (1967).

The following arguinent has been made against reliance on the less-drastic-means test in first amendment litigation:

[U]nless the Court adopts a priori notions of what is and is not protected expression or forbidden means, each different case will require a new choice between the conflicting values of the state's interest and the first amendment values. Since the Court lacks the competency to measure the relative efficiency, cost, and repressive effect of alternative measures, consideration of less drastic means cannot provide any form or structure to this choice.

Note, Less Drastic Means and the First Amendment, 78 YALE L.J. 464, 474 (1969). There may be zoning disputes in which the same lack-of-competence arguments could be raised. But in the ordinary zoning controversy, especially when a particular land use has been excluded from a vast, developing territory, the less-restrictive-alternative principle is sensibly imvoked to protect the rights of property owners, developers, and consumers, and, where pertinent, to insure against blanket barriers to the entry of lowand moderate-income or minority people. However, courts have understandably refrained from striking down zoning ordinances when they could not be sure what the extent of harm was or had difficulty ascertaining whether the alternative chosen by the local government was actually more restrictive than necessary to achieve legitimate ends.

164. Girsh Appeal, 437 Pa. 237, 244-45, 263 A.2d 395, 399 (1970). 
compatible land uses, not unwanted persons. Even the most rabid home-rule advocates in the state legislature would not sanction the use of zoning powers in intercommunity warfare to enhance tax bases, as by zoning out apartments and welcoming industry.

The Pennsylvania suprenie court most recently reiterated the regional implications of exclusionary zoning in Girsh Appeal, ${ }^{105}$ holding that a township cannot refuse to provide for apartments:

Nether Providence Township may not permissibly choose to only take as many people as can live in single-family housing, in effect freezing the population at near present levels. Obviously if every municipality took that view, population spread would be completely frustrated. Municipal services must be provided somewhere, and if Nether Providence is a logical place for development to take place, it should not be heard to say that it will not bear its rightful part of the burden. Certainly it can protect its attractive character by requiring apartments to be built in accordance with (reasonable) setback, open space, height, and other light-and-air requirements, but it cannot refuse to make any provision for apartment living. The simple fact that someone is anxious to build apartments is strong indication that the location of this township is such that people are desirous of moving in, and we do not believe Nether Providence can close its doors to those people. ${ }^{160}$

Clearly, these Pennsylvania zoning cases do not come within a "poverty" rubric. Nether Providence, if it ever zones for apartments, will probably get luxury units. ${ }^{107}$ Not even the large-lot zoning cases involve poverty law, since large-lot zoning usually takes place in expensive but exurban places where there is little eniployment for working-class people. Nonetheless, in some of these communities, a lessening of restrictions would be salutary. Industry is moving from most cities; ${ }^{168}$ inevitably some will reach the nether provinces, creating a demand for moderately priced housing. A community that fails to provide for this denand invites judicial intervention in its land use processes.

Having discussed large-lot zoning and the exclusion of apartments, yet another type of exclusionary ordinance can be mentioned to suggest the range of potentially offensive laws communities have enacted. In the Borough of Glassboro, New Jersey, at least 70 percent of the units in all new garden developments must have no more than one bedroom, no more than 25 percent may liave two bedroons, and no more

165. 437 Pa. 237, 263 A.2d 395 (1970).

166. Id. at 244-45, $263 \mathrm{~A} .2 \mathrm{~d}$ at 398-99.

167. See Washburn, Apartments in the Suburbs, 74 Dick. L. REv. 634, 636 (1970).

168. See generally National Committee against Discrimination in Housing, Inc., Jobs and Housing, Mar. 1970 (Interim Report) [hereinafter cited as NCDH Report]. 
than 5 percent may have three. ${ }^{169}$ The standard justification for such ordinances, which have become fairly common, ${ }^{170}$ is fiscal: more bedrooms mean more children; hence, higher property taxes. New Jersey is among the states that place greatest reliance on local property taxes to support schools; state subvention of school costs in New Jersey is miniscule. ${ }^{171}$ This leads naturally enough to protective fiscal zoning. A New Jersey superior court in the most well-reasoned decision to date on bedroom ordinances, invalidated the bedroom limitations observing:

The effort to establish a well balanced community does not contemplate the limitation of the number in a family by regulating the type

169. Molino v. Mayor and Council of Glassboro, No. L. 21255 PW (N.J. Super. Ct., filed July 27, 1971). The ordinance was enacted February 10, 1970. But see Malmar Associates v. Board of County Comm'rs, 260 Md. 292, 272 A.2d 6 (1971).

170. Where multiple dwellings are permitted (as of right or by special permit) on vacant land outside of large cities, the frequent practice (at least in some parts of the country) is to restrict the number of bedrooms within dwelling units in such buildings. This policy may be carried out by exphcit requirement in the zoning law, or by inserting such a requirement as a condition in the grant of a special permit, or even by informal pressure. See Williams and Wacks, Segregation of Residential Areas Along Economic Lines, 1969 WIs. L. Rev. 827, 843. A frequent provision requires that 80\% of the dwelling units in apartment buildings shall have only one bedroom, but permits up to $20 \%$ with two bedrooms-and one with more. However, the percentages cover a considerable range; and on rare occasions a small percentage is allocated for threebedroom apartments. The policy is a rather clear-cut one: for apartment-dwellers, not more than one child, or perhaps two children living crowded together.

171. In 1965-66, local support for schools accounted for an average of $53.1 \%$ of total expenditure among the states, but in New Jersey, local governments were paying $74.4 \%$ of the school bill. State contributions in the U.S. average $39.1 \%$ to New Jersey's 21.2\%. National Education Association, Ranking of the States, Tables 71-73 (Research Report 1966-R-1). The significance of this factor was noted in an Urban Land Institute study:

If the developer is required to meet the cost of local improvements, singlefamily homes, built to sell at the low end of the medium price range, may be expected to pay their own way over a period of time for local public services appropriately charged to them in most states. Only in a few states which, like New Jersey, rely heavily on the property tax to finance local public services and where state aid is relatively low, are expenditures appropriately allocated to such subdivisions likely to exceed the revenues they generate. While not established by this study, an inference may be drawn that the localities best able to meet the public service needs of lousing developments, priced even lower than those herein studied, are likely to be found in states where public fimancing is state-oriented and where heavier reliance is placed on state-administered income and sales taxes than on the local property tax.

R.I. Mace \& W.J. Wicrer, Do Stngle-FamiLy Homes Pay Their Way? (Urban Land Institute Research Monograph No. 15, 1968).

School expenditures are the main impetus for fiscal zoning. Thus, Serrano v. Priest, 5 Cal. 3d 584, 487 P.2d 1241, 96 Cal. Rptr. 601 (1971), the recent Califorma supreme court decision holding the system of local financing for schools unconstitutional, has been heralded as a major advance against exclusionary zoning. L.A. Times, Sept. 1, 1971, § 2, at 6, col. 1 .

The fiscal motivation for such restrictions is obvious: they are directed against families with school children, in order to avoid the cost of educating 
of housing. The attempt to equate the cost of education to the number of children allowed in a project or a community has no relation to zoning. The governmental cost must be an official concern but not to an extent that it determines who shall live in the municipality.

No municipality may isolate itself from the difficulties which are prevalent in all segments of society. ... . Zoning is not a boundless license to structure a municipahty. ${ }^{172}$

The extent to which a bedroom limit is truly exclusionary depends on the demand for the impermissible units and whether it would be satisfied but for the ordinance. In one town such an ordinance may serve to prevent overbuilding. Failure to reckon with changing demographic patterns has left Washington, D. C., for instance, with many vacant apartments, abandoned because the units were built after the Second World War for singles and childless couples and are not large enough for current needs. If a community has good reason to expect that developers will build the wrong size apartments, inviting rapid abandonment, few courts will intervene as the community tries to facilitate the proper mix. A community could, of course, interpose this rationale as a prop for an otherwise impermissible ordinance, so courts ought to look quite closely at the basis for municipal projections and stand ready to review the trends periodically. A community that actively plans to increase its school capacity and in the meanwhile restricts bedroom size just long enough to enable the construction of needed elementary schools may also be supported. For either of these purposes, bedroom controls might be regarded as reasonable. If courts do here what they have done in large-lot zoning cases, they can be expected to allow those controls not likely to cause extensive harm in the rental marketplace.

Glassboro selected a rather obvious device for trying to himit the nuniber of children. A more subtle arrangeinent would have been to establish, as many cities have, building density ordinances that

such children. (In Warrentown, New Jersey, the zoning ordinance actually limits occupancy in such buildings to one pre-school child per dwelling unit, and forbids any occupancy by school-age children. It seems doubtful that many lawyers would take a case to defend such a restriction on a contingency fee.) Obviously, to the extent that multiple-dwelling housing is required for normal families with children, the use of this device effectively prevents development of such housing. Note the irony-that in many such areas, singlefamily houses are all required to be large, and apartments must all be small.

Such a flat prohibition on families with children, or rather on such families who rent housing rather than owning it, is certainly dubious constitutional law. N. Williams, Treatise on the Law of Zoning 23-1, 23-2, 1971, (unpublished copy on file with the author) [hereinafter cited as Williams].

172. Molino v. Mayor and Council of Glassboro, No. L 21255 PW, at 10 (N.J. Super. Ct., filed July 27,'1971). 
relate lot area to the floor space permitted on the lot. ${ }^{173}$ Under a floorarea ratio (FAR) of 1.0, for example, the developer could construct a one-story building covering the entire lot, a two-story structure covering 50 percent of the lot, or a ten-story building covering 10 percent of the lot. FAR systems usually take no account of the number of units or offices in a building; thus an incentive is created to crowd as many small apartments or offices into the space as can be rented profitably. This is, however, less certain to preclude two-, three-, and four-bedroom apartments than the Glassboro approach.

In fact, as the demand for large apartments goes unmet and those who loaded their buildings with sinall units experience vacancies, developers and lenders are bound to take heed. Bedroom limits prevent their responding quickly; FAR restrictions do not. Thus it is not surprising that while the former have received a mixed judicial reaction, ${ }^{174}$ the latter have been uniformly sustamed. ${ }^{175}$

\section{The Kinds of Interests Affected}

At first glance the zoning cases seem distinguishable froin Supreme Court opinions like Goldberg, Shapiro, and even Boddie. The Supreme Court was quite careful in Boddie to note that judicial intervention had been evoked by a denial of access to a process. The problem in zoning can also be characterized as largely procedural. This is so despite the fact that in the usual zoning dispute, the property owner is invited to the public hearing and has ample opportunity to state his case, challenge hostile speakers, and attempt to persuade planning commissioners and councilmen.

\footnotetext{
173. FAR [floor-area ratio] regulations have been widely adopted in the larger American cities. All the five largest cities with a population of over a million (New York, Chicago, Los Angeles, Philadelphia and Detroit) have such regulations in residential districts, although only in the higher-density districts in Detroit. About one-half of the cities with a (1960) population between 500,000 and one million use such controls, to varying degrees-with more such requirements in the more recent and the more sophisticated ordinances, as in Baltimore and Boston. A somewhat similar situation prevails as to suburban ordinances, except that FAR requirements are less common there.
}

Williams 4-8.

174. But see Molino v. Mayor and Council of Glassboro, No. L 21255 PW (N.J. Super. Ct., filed July 27, 1971).

175. Broadway, Laguna, Vallejo Ass'n v. Board of Permit Appeals, 62 Cal. 2d 767, 427 P.2d 810, 59 Cal. Rptr. 146 (1967). Cf. Village of Bronxville v. Francis, 206 Misc. 339, 134 N.Y.S.2d 59 (Sup. Ct., Westchester County, 1954), modified and aff'd, 1 App. Div. 2d 236, 150 N.Y.S.2d 906 (1956), aff'd, 1 N.Y.2d 839, 135 N.E.2d 724, 153 N.Y.S.2d 220 (1956); Pondfield Rd. Co. v. Village of Bronxville, 141 N.Y.S.2d 723 (Sup. Ct., Westchester County, 1955), affd, 1 App. Div. 2d 897, 150 N.Y.S.2d 910 (1956), affd, 1 N.Y.2d 841, 135 N.E.2d 725, 153 N.Y.S.2d 221 (1956); Wilcox v. Zoning Bd. of Appeals, 17 N.Y.2d 249, 217 N.E.2d 633, 270 N.Y.S.2d 569 (1966). 
Actually, these rights are illusory when the standards for municipal action are vague or if zoning exceeds its authorized function, reflecting only the will of the nost vocal neighbors. Similarly, when the township through land use controls welcomes industry and shuns housing that working people can afford, adjoining communities, which get the apartments and lose the good ratables, may want to protest vehemently. But there is rarely an impartial panel to hear thein-save the courts.

Many zoning cases, Pennsylvania's among them, resenible the jury selection controversies. The results were so far from those expected if fair procedures had been used that a defective process conld be imferred from the substantive results. Accordingly, a special inquiry becane appropriate to conipel the community either to justify the steps it used in forming its final plan or to go back and try again.

Federal court participation in sone zoning disputes may be more readily induced by statutory than constitutional law. Already, federal courts have expressed the hope that HUD, under the affirmative action mandate of the 1968 Fair Housing Act, ${ }^{176}$ would attempt to counter suburban land use practices that result in the barring of minorities. ${ }^{177} \mathrm{~A}$ mam focus of attention in exclusionary zoning is on the rapid increase in suburban job opportunities coupled with a shortage of conveniently located, nıoderately priced housing. Zoning laws are deemed pernicious if less prosperous and predominantly black employees must spend an hour or more getting to work while white people who own houses in the area that were built before the higher zoning standards went into effect are able to live close by. ${ }^{178}$ Although federal courts have not customarily addressed this sort of issue, federal law does prohibit any forn of racial discrimination in employment, ${ }^{170}$ and some have argued that a business relocation to a suburb where minority employees cannot find housing might constitute a discriminatory einployment practice. ${ }^{180}$

176. 42 U.S.C. $\$ 3604$ (1970).

177. This was the thrust of Shannon v. United States Dep't of HUD, 436 F.2d 809 (3d Cir. 1970). Pursuant to that decision, au order was issued in the district court [Civ. No. 69-197 (E.D. Pa.)] for HUD to develop an institutionalized inethod for fulfilling its obligations under the 1964 and 1968 Civil Rights Acts.

178. See NCDH Report 16-17; Suburban Action News, FCC and EEOC Urged to Stop AT\&T Move to Discriminatory Suburb (White Plains, N.Y., June 2, 1971); Suburban Action News, General Electric's Move to All-White Suburb Jeopardizes its Federal Governmeut Contracts (White Plains, N.Y., Juue 14, 1971).

179. Civil Rights Act of $1964 \S \S 701$ et seq., 42 U.S.C. $\S \S 2000$ e et seq. (1970).

180. However, a business movc to the suburbs without a concomitant effort to provide housing opportunities for all employees is quite different from the ordinary discriminatory employment practice. While the usual forms of discrimination are within company discretion, providing housing may not be. No one wants to be disqualified from his job, but many people prefer to commute rather than uproot their families when 
Is this plausible? Although the Supreme Court has yet to hear such a case, Griggs v. Duke Power Company, ${ }^{181}$ decided March 8, 1971, may be relevant. In that case stringent employment examinations worked as a screen against minority applicants and were held impermissible. ${ }^{182}$ Griggs is distinguishable from the relocating-employer situation since employers are not directly responsible for the enforcement of fair housing laws, and housing opportunities are rarely as mucl within a company's discretion as are employment tests. Yet, when housing needs, zoning laws, and perhaps a past history of job discrimination intersect, Justice Burger's words in Griggs may be germane:

Congress has now required that the posture and condition of the jobseeker be taken into account. It has-to resort again to the fableprovided that the vessel in which the millk is proffered be one all seekers can use. The Act proscribes not only overt discrimination but also practices that are fair in form, but discriminatory in operation. The touchstone is business necessity. ${ }^{183}$

If federal courts began scrutinizing plant relocations, as they have other employment practices, to assess the availability of housing opportunities, suburban comınunities might quickly realize that zoning cannot be used to attract industry and repel moderately priced housing. A policy of matching suburban plants to increased housing opportunities has already been adopted by the General Services Administration (GSA) as part of its standard for locating federal installations ${ }^{184}$ and by HUD in its site-selection criteria for federally assisted housing. ${ }^{185}$ It has also been urged before a number of administrative panels charged

job sites are shifted. When all lower paid employees are disadvantaged by the move, employers are under pressure to increase wages in order to prevent excessive absenteeism and turnover.

181. 401 U.S. 424 (1971).

182. The issue in Griggs was whether a power company could require a high school education or the passing of a generalized intelligence test as a condition of employment in, or transfer to, jobs when:

(a) neither standard is shown to be significantly related to successful job per-

formance, (b) both requirements operate to disqualify Negroes at a substan-

tially higher rate than white applicants, and (c) the jobs in question formerly

had been filled only by white employees as part of a longstanding practice of giving preference to whites.

Id. at 426 .

183. Id. at 431 .

184. According to Mr. R. Peter Hollingsworth, GSA Region IX Office, GSA is preparing a handbook that elaborates new site selection standards. The potential socio-economic and ethnic impact of a proposed installation will be evaluated under these new gnidelines. The new GSA procedures are based on the Intergovernmental Cooperation Act of $1968 \S 5,42$ U.S.C. $\$ \S 4201-44$ (1970), and the National Environmental Policy Act of 1969, 42 U.S.C. $\$ \S 4321-47$ (1970).

185. 24 C.F.R. $\S 200$ (1971). 
with assuring fair employment opportunities. ${ }^{186}$ While there are substantial limits presently to private enforcement, regulatory law in this field is certain to expand. As initiatives are taken to strengthen HUD, GSA, and state equal opportunity guidelines, state courts may be encouraged to follow the lead of the Illinois court that invalidated a half-acre requirement in Cook County, partly because the site was an easy 15-minute drive froin an industrial district and the court surmised that people interested in living there miglit be better able to afford smaller lots. ${ }^{187}$

This discussion of jobs and housing in the suburbs indicates the overlap of the factors of extent and kind. Manifestly, the greater the impact of land use controls in separating inoderate-income housing from new job sites, the more it affects a special kind of interest: access to employment opportumities. The factors of extent and kind are nonetlieless distinct. Some kinds of interests would receive protection even if the extent of harm were negligible. In Lackawanna, for instance, the city liad been using its zoning powers to confine blacks to the wards inundated witl industrial pollution. Suppose it had been slown that federal funding were available for, at most, 100 units of subsidized liousing and that without subsidies most developers would not risk defying the community stricture against integrated housing. Then to allow the Kennedy Park Homes to be built outside an area of minority concentration would be a futile, even trivial, gesture. Still, the kind of interest at issue (race) would liave been sufficient to justify setting aside the ordinance.

Yet in other cases the extent of harm alone will condition the demand placed on city officials in proving the reasonableness of their zoning laws. This has been the explicit basis of the Peumsylvania decisions. Zoning, that state supreme court has urged, is the attempt to reconcile competing uses. Accordingly, the zoning sclieme that seeks reconciliation through the total exclusion of some uses, like the pursuit of peace by waging war, is itself a contradiction in terms and accorded special scrutiny independent of the kind of interest affected.

\section{Form}

Zoning explicitly to exclude on a basis of race, wealth, family

186. E.g., letter of July 8, 1971, from David H. Ben-Asher, New Jersey Deputy Attorney General, to James H. Blair, Director, New Jersey Division on Civil Rights, concerning National Comm. Against Discrimination in Housing v. Township of Mahwah, New Jersey. Mr. Ben-Asher's letter concludes that under the Law Against Discrimination, N.J. Stat. AnN. § 10:5-1 et seq. (Supp. 1971), the New Jersey Division of Civil Rights does not have jurisdiction to hear the Mahwah case.

187. Marquette Nat'1 Bank v. County of Cook, 24 Ill. 2d 497, 182 N.E.2d 147 (1962). 
size, or borrowing ability is simply unlawful. Even absent the fourteenth amendment and cases like Buchanan and Edwards, most state court readings of the applicable zoning enabling legislation would suffice.

[A] municipality under the cloak of its zoning power, might provide that no house costing less than a certain sum should be erected in a specified area. This it cannot legally do. For obviously such a provision or regulation could not properly be said to be made "with a view of conserving the value of property and encouraging the most appropriate use of land throughout such municipality." R.S. 40:55-32, N.J.S.A. No person under the zoning power can legally be deprived of his right to build a house on his land merely because the cost of that house is less than the cost of his neighbor's house. ${ }^{188}$

The enabling laws-New Jersey's is typical-sanction the conservation of property values, but, presumptively at least, not at the expense of barring entirely the construction of modest dwellings. Admittedly, a city bent on excluding those whose incomes fall below $\$ 10,000$ a year can approximate its objective through provisions for large lot sizes, deep setbacks, extravagant landscaping, and minimum building sizes as readily as via an impermissible $\$ 25,000$ minimum on house building costs. If there is a strong market for expensive houses in the town, this will prove perfectly feasible and the zoning law will only have codified the market.

Yet when the form of the alleged exclusionary ordmance becomes more neutral, legitimate defenses can often be raised on its behalf. Minimum building cost provisions, the few times attempted, were swiftly annulled. Since construction costs per square foot are fairly predictable for any given area, communities have often turned to prescribing mininnum building sizes. Judicial reaction has been mixed. Sometimes the requirements are so modest that to allow smaller dwellings might be tantamount to encouraging deceptive sales tactics to induce the purchase of unlivable houses. ${ }^{189}$ In one leading case, the result was arguably to

188. Brookdale Homes, Inc. v. Johnson, 123 N.J.L. 602, 605-06, 10 A.2d 477, 478 (Sup. Ct. 1940), affd., 126 N.J.L. 516, 19 A.2d 868 (Ct. Err. \& App. 1941).

189. The Pennsylvania supreme court refused to sustain a Bucks County ordinance that provided minima of $1,000,1,125,1,400$, and 1,800 square feet in various districts.

It does not follow that a minimum scale of habitable floor space in a home may not have a reasonable, direct and proper relation to the health and morals, and possibly, to the safety of the occupants of the house or of the commurity in general, because it is well known that an overcrowding of persons or of meinbers of a large family in a tiny house or in a small room or rooms might undoubtedly have a direct effect on their health and morals. But if a 1000-minimum habitable square feet is reasonable and proper for every home in one district and does not adversely affect the health, morals or safety of the occupants of such a house, 1125 square feet of habitable floor area in a nearby 
discourage small summer cottages in favor of year-round residences. ${ }^{100}$ It is difficult to plead on behalf of an unrestricted second-home market when there is ample demand for year-round residences-as long as the restrictions do not preclude middle-income buyers. Occasionally the courts have been influenced by aesthetic considerations. ${ }^{101}$ Assuming ample opportunity to build at a variety of densities, there is little compelling reason to resist the preservation of some luxury areas.

As with overbroad classifications that may have had their mipetus in racial enmity, zoning for expensive residential use in the absence of strong buyer demand will bring major landowners to city hall to protect the value of vacant acreage. While a rule aimed exclusively against poor people might pass without opposition, a rule that gluts the market with large lots will only be enacted over the objections of a well-heeled minority. The fight against an exclusionary ordinance may still be lost, but seldom by default.

\section{Uniqueness}

The clearest and most recent illustration of heightened scrutiny due to "uniqueness" is $G \& D$ Holland Construction Co. v. City of Marysville, ${ }^{102}$ a California case. The Holland site was properly zoned on

house cannot adversely affect the health, morals or safety of that home or of that community.

Medinger Appeal, 377 Pa. 217, 224-26, 104 A.2d 118, 122 (1954). By contrast, the Massachusetts court sustained a sliding scale of required minimum floor space for apartments of various sizes: 468 square feet for a 3-room apartment, 610 for a 4-room apartment, and so on. Massachusetts has a unique law forbidding any minimum-buildingsize regulation requiring more than 768 square feet. MASs. GEN. LAWS ANN. ch 40A, $\S 2$ (1968). Garelick v. Board of Appeals of Franklin, 350 Mass. 289, 214 N.E.2d 60 (1966). Taken together, the Pennsylvania and Massachusetts cases can be seen as validating minimum size requirements only when consumers might otherwise be misled into buying or renting uninhabitable space.

190. Lionshead Lake, Inc. v. Wayne Township, 8 N.J. Super. 468, 73 A.2d 287 (Law Div.), rev'd, 9 N.J. Super. 83, 74 A.2d 609 (App. Div. 1950), rev'd, 10 N.J. 165, 89 A.2d 693 (1952), appeal dismissed, 344 U.S. 919 (1953). Most of the houses in the Lionshead Lake project that were built before the minimum size ordinance have been enlarged. Shortly after the case was decided, the town increased its minimums considerably, thus discouraging the development of moderately prices houses.

191. Since an ordinance was written to require more floor space in a two-story house than a one-story, and still more in a two-story house without an attached garage, "the real purpose of these regulations was clear enough-to make a house look big, with no undue concern with the question of whether or not in fact the house was big. Williams 30-40. Justice Jacobs of the New Jersey supreme court regarded this provision as a legitimate aesthetic exercise. Other courts have been less willing to condone minimum building size ordinances for aesthetic objectives. Baker v. Somerville, $138 \mathrm{Neb}$. 466, 293 N.W. 326 (1940).

192. 12 Cal. App. 3d 989, 91 Cal. Rptr. 227 (3d Dist. 1970). The requirement that zoming laws be of general applicability, or at least that the commnnity be able to articulate its objectives with sufficient clarity so that courts can determine 
January 5, 1970, when Holland apphed for a building permit to construct a 236 project. Just before the permit would have been obtained, people in the neighborhood learned about the proposal and initiated a rezoning, covering only a single square block, that would foreclose Holland's plans. The alleged explanation was that, on January 15, storm drainage had overloaded the sewage system. Holland sued to set aside the precipitous rezoning; at trial his challenge was dismissed by summary judgment. ${ }^{193}$ The Third District court of appeals reversed and remanded, noting that although ordinarily "any reasonable basis" is enough to support legislation, this case justified an exception to the ordinary standard of review:

The principle limiting judicial inquiry into the legislative body's police power objectives does not bar scrutiny of quite a different issue, that of discrimination against a particular parcel of property. ....

$\cdots \cdots$

.. . Although a real problein of municipal sewage disposal existed, the affidavits exhibited only a chimerical connection between that problem and the highly selective reduction of population density

whether like cases are being treated alike by local authorities, has been restated often by most of the state courts in which zoning litigation is frequent. Among the clearest expositions of the presumption against uniqueness is Justice Keating's in Udell v. Haas, 21 N.Y.2d 463, 469-70, 288 N.Y.S.2d 888, 893-94, 235 N.E.2d 897, 900-01 (1968):

[T] coinprehensive plan is the essence of zoning. Without it, there can no rational allocation of land use. It is the insurance that the public welfare is being served and that zoning does not become nothing more than just a Gallup poll.

Moreover, the "comprehensive plan" protects the landowner from arbitrary restrictions on the use of his property which can result from the pressures which outraged voters can bring to bear on public officials. . . .

... [Z]oning may easily degenerate into a talismanic word, like the "police power," to excuse all sorts of arbitrary infringements on the property rights of the landowner. To assure that this does not happen, our courts must require local zoning authorities to pay more than mock obeisance to the statutory mandate that zoning be "in accordance with a comprehensive plan." There must be some showing that the change does not conflict with the community's basic schenie for land use.

Justice Keating thus rejected the populist notion forwarded by Justice Black in Valtierra, at least when it comes to land use decisions affecting property. Conceivably Justice Black would have agreed that in zoning matters "devotion to deinocracy" is carried too far if people are allowed to vote on particular zoning applications, for he demonstrated his respect for the institution of private property in a wide range of cases. E.g., National Bd. of Y.M.C.A. v. United States, 395 U.S. 85, 99 (1969) (dissenting opinion discussing when a police action constitutes a "taking"); Bell v. Maryland, 378 U.S. 226, 318 (1964) (dissenting opinion concerning civil rights sit-in and state trespass action); Amalgamated Food Employees Umion v. Logan Valley Plaza, Inc., 391 U.S. 308, 327 (1968) (dissenting opinion coucerning peaceful picketing on private property in a shopping center).

193. G. \& D. Holland Constr. Co. v. City of Marysville, No. 20849 (Cal. Super. Ct., Yuba County, Aug. 20, 1971). 
in a single square block of the neighborhood.

The issues framed by the pleadings evoked judicial review more intense than that posed by a generalized exercise of police power. ${ }^{104}$

It is important to note that racial prejudice and economic exclusion were not involved in the holding. The appellate court's mandate-an exacting scrutiny of the immediate purpose, ultimate objective, and circumstances of the erzoning - was predicated solely on the apparent application of the rezoning to only a particular parcel to thwart a single proposed project. On retrial, the superior court "received evidence regarding the immediate purpose, ultimate objective and the circumstances attending the adoption of these ordinances," found "a discretionary design against this parcel and its owners," and granted Holland's petition for writ of inandate. ${ }^{105}$

An objection may be raised to affording "mere" business interests the saine degree of protection against discrimmatory treatment that racial, class, or economic minorities receive. When business interests are sufficiently harmed, landowners can claim compensation on the promise of the fifth amendment that private property will not be taken without just compensation. However, the possibility of fifth amendment claims against the taking of property does not deter most zoning abuses. The usual rule is that if any reasonable use can be found for the site, no compensation is due no matter how much the landowner loses as a result of the zoning. ${ }^{190}$ This is partly a function of a quirk im zoning law. Land uses that predate the enactment of a zoning ordinance are sheltered. No rights accrue, though, in land ownership alone-even on land purchased at a price reflecting a reasonable belief that it could be used in a way subsequently frustrated by a change in the zoning code. ${ }^{107}$ Maybe this anomaly reflects nothing save a coolness toward the land speculator, or perhaps it derives from the Henry George philosophy that increments in land value belong to the community on the notion that the cominunity creates such values.

194. 12 Cal. App. 3d at 994-96, 91 Cal. Rptr. at 230-31 (1970).

195. G. \& D. Holland Constr. Co. v. City of Marysville, No. 20849 (Cal. Super. Ct., Yuba County, Aug. 20, 1971).

196. See Town of Surfside v. Watson, 111 So. 2d 674 (Fla. App. 1959); Levitt Inc. v. Village of Sands Point, 6 N.Y.2d 269, 273, 189 N.Y.S.2d 212, 214, 160 N.E.2d 501, 503 (1959); Schwartz v. Lee, 28 App. Div. 2d 921, 282 N.Y.S.2d 141 (1967); Long Island Land Bureau v. Young, 7 Misc. 2d 469, 159 N.Y.S.2d 414 (1957); Helms v. City of Charlotte, 255 N.C. 647, 122 S.E.2d 817 (1961). But see Umited States v. Causby, 328 U.S. 256 (1946); Pennsylvania Coal Co. v. Mahon, 260 U.S. 393 (1922).

197. See City of Miami Beach v. Schaner, 104 So. 2d 129 (Fla. App. 1958), aff'd, 112 So. 2d 838 (Fla. 1959); Anthony v. City of Kewanee, 79 IIl. App. 2d 243, 223 N.E.2d 738 (1967). 
In any event, it is simply an error to say that the landowner receives compensation for adverse zoning. Furthermore, a businessman will not be compensated for loss of growth potential. Indeed, foreclosed opportumities may cause the business to fail; once again, no compensation is due. The promise of the just compensation clause, since it applies to "takings" and not to most forms of "regulation," places an extraordinary burden on that thin distinction.

In addition to supplementing the fifth amendment's promise of security to property owners, the primciple that zoning laws must be of general applicability serves others equally well. When projects are thwarted due to racial or economic prejudice, proof of impermissible motive is difficult to obtain, and even when it is secured, courts are reluctant to impute the bias of protestors at a public hearing to the city councilmen who vote against a project. Aberrational treatment may be all the 236 developer is able to show. It is the sane principle that allows neighbors to challenge the variance for a gas station or a liquor store in a residential area. "Spot" zoning tends not to enjoy the usual presumption of validity, and, therefore, instead of forcing the neighbors to prove a councilman used poor judgment, or was bribed, the burden shifts to the zoning authority to justify its curious result. ${ }^{108}$

An issue often present in uniqueness or "spot" zoning cases is low idiosyncratic the special application must be. Attempts to fraine a rule in terms of the area covered by the change are futile. ${ }^{199}$ But one variable of particular significance has emerged for exclusionary zoning: the quantum of economic injury a property owner may be compelled to abide when the impact of a zoning law falls more lieavily on him than on his neighbors is often made to depend on how vital the objectives of the particular ordinance appear to be. In Consolidated Rock Products Co. v. City of Los Angeles, ${ }^{200}$ a California court allowed a nearly total diminution in value when the City of Tujunga outlawed quarrying, since the Sunland-Tujunga area is well known as a refuge for people with respiratory ailments. In large-lot zoning cases, however, courts in Ohio ${ }^{201}$ and New York ${ }^{202}$ have set aside such acreage restrictions when substantial value declines were likely. These

198. See, e.g., Cassinari v. City of Union City, 1 N.J. Super. 219, 63 A.2d 891 (N.J. Super. 1949); Cassel v. Mayor and City Council of Baltimore, 195 Md. 348, 73 A.2d 486 (1950).

199. Compare Nelson v. Board of Zoning Appeals, 240 Ind. 212, 162 N.E.2d 449 (1959) with Nelson v. Board of Zoning Appeals, 158 N.E.2d 167 (Ind. App. 1959).

200. 57 Cal. $2 \mathrm{~d}$ 515, 370 P.2d 342, 20 Cal. Rptr. 638, appeal dismissed, 371 U.S. 36 (1962).

201. Grant v. Washington Township, 1 Ohio App. 2d 84, 203 N.E.2d 859 (1963).

202. In re Fulling v. Palumbo, 21 N.Y.2d 30, 286 N.Y.S.2d 249, 233 N.E.2d 272 (1967). 
results were reached by suspending the usual presumption of validity and allocating to municipal officials the task of justifying the need for their ordinances. ${ }^{203}$

Reference to the large-lot zoning cases redirects attention to the first factor discussed, extent of harm. Large-lot zoning may be subject to special scrutiny on a number of grounds, and by delineating thein the distinctions between extent, uniqueness, and kind can be illustrated. If an entire region is zoned for large lots, driving up the price of land, extent alone justifies special scrutiny. It may be that no one landowner is affected uniquely. Indeed, the dollar loss for each owner may be so modest as not to be provable at all. Even so, the aggregate deprivation justifies an active judicial review. Conversely, zoning authorities niay have reserved so much land for small lots in a neighborhood as to dull the snob appeal of a few parcels zoned with high minimuin acreage requirements. Why these few tracts are subject to unique, harsh regulation is a question that nust be answered convincingly if the ordinance is to be sustained.

Rarely will the elements of uniqueness and extent be combined. Zoning is a pohitically responsive process; all the landowners im a region are seldom going to be made to suffer precipitous value declines. For this reason I have distinguished the degree of deprivation and uniqueness from the notion of extent. A few people niay bear the brunt of a zoning ordinance but their injury is likely to be unique, not extensive. We have seen at least one exception. The Los Angeles city council eliminated all quarrying in Sunland-Tujunga; there had to be a good reason for it, and there was. Had all quarrying been outlawed in the City of Los Angles, an even better case would have been required. Because transportation is a inajor component of cost for most quarried materials, exclusions that force these inaterials to be supphied from outside the region can raise construction costs enough to merit close judicial review. The courts will want to be sure that zonmg officials have done all they can to reconcile inconipatible uses before imposing such an extensive prohibition. Since Consolidated Rock owned other sites in the area, and not all of them were proscribed for quarrying, the company continued to prosper despite the apparent loss at the Sunland-Tujanga site. However, even this loss would not have been tolerated had the ordinance applied just to this one operatoragain, absent a compelling explanation. In framing this case, the outlawed quarry operator should be careful to separate a complaint based on the uniqueness (or degree) of the deprivation-that only he is affected and he is very much hurt-from one based on the extent of harm-that consumers and other operators will be put to extraordi-

203. Id. at 33,286 N.Y.S.2d at 251,233 N.E.2d at $273-74$. 
nary costs as a result of a total exclusion from an area so large as to suggest ill-considered planning.

\section{Special Zoning Treatment for Low- and Moderate-Income Housing}

The claim has been inade that low- and inoderate-income projects ought to be removed from the reaches of local law. This was the thrust of the supremacy clause argument that the Valtierra Court rejected in a word. ${ }^{204}$ There is little in the way of a social welfare argument that would justify exempting assisted housing from the prevailing density and design standards. ${ }^{205}$ For one thing, if contractors are free to build out of scale with the neighborhood, one performance criterion for subsidized housing - to avoid stigmatizing its inhabitants - might be thwarted. There are producers of assisted housing who incline toward building repetitive, shoddy units. HUD-FHA standards are geared to prevent this. But as specific as the government's minimum property standards are, they focus on construction details and often fail to assure adequate design. The HUD-FHA field staff in most cities is overwhelmed with work and beset with a need to meet production quotas. This press for output sometimes results in the approval of ill-conceived plans, especially when the builder who proposes them can be counted on to meet his scheduled completion date. Nor do buyers and renters of subsidy housing provide the same discipline as consumers in the private market. When the cost to the consumer has been reduced by a subsidy, comparison shopping becomes futile; all he considers is whether the unit is worth the price he must pay. Developers realize this and some take advantage of it by overpricing and underbuilding. ${ }^{206}$

204. 402 U.S. at 140.

205. For reasons detailed in note 208 infra, the programs most affected by zoning are the interest subsidy programs. These cater to moderate-income, not to low-income, families. The typical family residing in a suburban 236 project is a Caucasian couple with one child. The head-of-household is under 30 . These people are scarcely the working class contemplated in the original legislation, nor are they a constituency especially needful of housing that fails to meet prevailing density or design standards. Since projects located in inner cities tend to serve minority people and people with greater needs, exclusionary suburban zoning, however improper, may result in a more equitable apportionment of 236 units than would otherwise occur.

206. As of March 31, 1971, 913,191 public housing units were under management. HUd, Status of Publicly Financed Low Rent Housing Programs, Series 600.10, Part I, Table 1 (1971). The Advanced Report of April 1, 1970, for the U.S. Census placed the total U.S. housing stock at $68,631,428$ housing units. Working from this available data, one finds that public housing accounts for approximately 1.3 percent of the total housing stock in the United States. If the government is to provide any substantial support for the production of housing, much of the impetus will, for practical reasons, probably have to cone from the interest subsidy or other moderate- and middle-incone programs.

A related indictment of the interest subsidy programs is that they have a tendency to escalate construction costs throughout the building industry by discouraging effi- 
Under the existing construction programs, shortcomings in some developers' plans will be noticed, if at all, only by discerning local government officials in the course of administering site-planning and designreview standards. Special protection of subsidy housing from local land use controls might remove such housing from the often helpful review

ciency. The FHA insures these mortgages, and payments are low since the buyer pays as little as one percent interest on a 40-year mortgage. National Housing Act $\S \S$ $235(2)(c), 12$ U.S.C. $\$ 1715 z(j)(2)(c)(1970), 236(c), 12$ U.S.C. $\$ 1715 z-1(c)$ (1970), and 24 C.F.R. $\$ 235.22$ (1971). The section 235 or 236 developer las little incentive to save money. To the contrary, the ligber the costs, the greater his profit margin is likely to be. In 236 (the apartment program) the builders' profits vary directly with construction costs. 24 C.F.R. $\$ 236.50$ (1971). In section 235 (the singlefamily sectiou) the houses are insured at a price fixed prior to construction with no express allowance for profit, but higher costs are absorbed $\mathrm{m}$ the form of miniscule increinents in the montly mortgage payment. A section 235 mortgage "shall provide for complete amortization not to exceed 30 years froin the date of the beginning of amortization, except that such maturity may be 35 or 40 years" if the Commissioner of FHA determines the mortgage cannot be paid in 30 years. 24 C.F.R. $\$ 235.22$ (1971). An additional $\$ 1,000$ construction cost per unit, when amortized over 30 years, would only require an additional $\$ 3.22$ per month repayment of primcipal and interest, that is, for the buyer who is only paying $1 \%$ interest on the inortgage. The buyer will pay for an overpriced house since all he cares about is whether for a given payment each month he is receiving a better deal than he would across the road on a house that probably carried a $7 \frac{1}{2}$ percent inortgage written for 25 years. See note 233 infra. The devastating effects on competition are clear; even the most efficient builders cannot compete without these subsidies. The contractor who would try to produce a good loouse for $\$ 16,000$ conventionally financed will be outsold by someone who puts up the same unit for $\$ 19,000$ with section 235 financing. The total cost of principal and interest for the two houses is $\$ 51,472$ for the $\$ 16,000$ house with conventional financing and $\$ 25,608$ for the $\$ 19,000$ house with the federal interest subsidy.

Without these programs, the building industry would liave cone close to collapse in 1969 and 1970. Boosted by the heavy use of the new prograns (sections 235 and 236), the share of housing starts represented by government subsidized programs jumped from 12 percent in 1969 to 25 percent in 1970 , the first year in whicl sections 235 and 236 had any real impact. In 1970, with approximately 60,000 starts under 235 and approximately 100,000 under 236, these two prograuns alone accounted for about 12 percent of all housing starts. Lilley, Washington Pressures/NAHB, 3 NAT'L J. 431, 493 C.2 (1971). They provide some moderate-income housing in or near center-city sitcs for truly moderate-income families. See Edson, Sections 235 and 236-The First Year, 2 URBAN LAWYER 17-18 (1970). Because the interest subsidy allows a below-market rent, people inight be induced to accept integrated housing who might not otherwise. The programs are being used to increase opportunities for minority contractors. If we could admit frankly the latent tendency of section 236 to be a program for middle-income people, the program could be used to encourage innovation in urban design. More families than ever will lave to reside in apartments and yet there has been too little innovation to replicate the amenities of the private residence in garden apartments. Just as urban renewal demonstrated the advantages of improved design to many a speculative office bnilder, section 236 could provide conventional developers with more thoughtful models for apartment living. The interest subsidy could remove some of the risks of innovation. Simultaneously it could be used for developments that would be attractive to upwardly inobile conples. If such families stayed on as their incomes rose, thereby paying a concomitantly ligher rent, the annual interest subsidy could be reduced eventually to zero. Furthermore, these programs are far more popular politically than public lousing, which dates back to 1937 , has been. 
of local officials and the vital protections embodied in enlightened building and zoning codes. Furthermore, such an exemption lacks congressional sanction. ${ }^{207}$ Largely on this basis, a district court ruling that public housing was exempt from local land use controls ${ }^{208}$ was reversed by the Sixth Circuit in Ranjel $v$. City of Lansing. ${ }^{209}$ The chief argument for these systems is that by mcreasing the demand for the existing stock, landlords will be given the wherewithal to improve maintenance. This is desirable since the major problem in slum housing is not that the nation has too low an output of new houses but rather that most poor people are likely to continue residing in older units that fall apart unless carefully maintained. Most advocates of various rent assistance plans do not contend that these should entirely supplant the production programs. They contend only that such programs would be a useful component of a national housing policy for aiding the poor and near-poor.

If assisted housing should not be exempt from local land use controls, neither should these laws become a subterfuge for barring the less affluent. Local zoning ought to take no account of either the intended occupants of a particular project or the method of financing (for example, federal insurance and subsidy). ${ }^{210}$ Legislation has been proposed in California to forestall communities from considering either of these tangential factors and to clarify the zoning enabling act. ${ }^{211}$ To prevent communities from discrimmating against such housing, special

207. See Lefcoe, HUD's Authority to Mandate Tenants' Rights in Public Housing, 80 YALE L.J. 463, 506-13 (1971).

208. 293 F. Supp. 301 (W.D. Mich. 1969). By chance, Michigan is a state that exempts by statute most public housing from most forms of local land use control. Michigan Honsing and Slum Clearance Act of 1933, Mich. CoMP. LAws $\$ 125.651$ et seq. (1948). The Michigan supreme court has recently construed the statute exempting local housing anthorities from municipal zoning ordinances. See Renshaw v. Coldwater Housing Comm'n, 381 Mich. 590, 165 N.W.2d 5 (1969).

209. 417 F.2d 321 (6th Cir. 1969) (per curiam).

210. Because sections 235 and 236 of the National Housing Act are the only subsidy programs that require no local approval other than the usual zoning and building code clearances, they are the housing programs unost often ensnarled in zoning controversies. In order to halt public lrousing or rent supplements, a city council need only refrain from passing the necessary enabling resolutions, while exclusionary zoning, on the other hand, may be their only defense against 235 and 236 housing. Local control provisions of other housing programs are as follows:

1) public housing-Housing Act of $1937 \S 15(7), 42$ U.S.C. $\S 1415(7)$ (1970) (local determination of housing need); Housing Act of $1937 \S 15(7)(\mathrm{b}), 42$ U.S.C. $\S 1415(7)$ (b) (1970) (local cooperation agreement); Housing Act of $1937 \S 10(c), 42$ U.S.C. $\$ 1410$ (c) (1970) (public housing subject to the "workable program" requirement of Housing Act of $1949 \S 101$ (c), 42 U.S.C. 1451(c) (1970));

2) leased units-Housing Act of 1937, ch. 896, § 23 (a)(2), 50 Stat. 899 (required approval by resolution of local governing body of section 23 leased units);

3) rent supplement-24 C.F.R. $\$ 5.15$ (c) (1971) (requires specific local government approval of reut supplement programs). See also "workable program" provisions in appropriations legislation.

211. A.B. 2946, Cal. Reg. Sess. (1971): 
permit and appeal provisions have been enacted in Massachusetts, ${ }^{212}$ and proposed elsewhere. ${ }^{213}$ To lessen the risk of impaction and distribute fiscal burdens equitably, regional distribution goals for low- and moderate-income housing have been voluntarily apportioned among cities in the Miami Valley of Ohio, ${ }^{214}$ are being studied by other regional authorities, ${ }^{215}$ and were mandated for Atlanta by a federal district court. ${ }^{210}$

While the above arrangements are consistent with a restrictive view of what cities are einpowered to do in the name of police power and within the bounds of state zoning enabling laws, ordinances that have been proposed favoring federally subsidized housing raise difficult questions about the proper uses of the zoning power. Fairfax County, Virginia, has enacted an ordinance that requires most multifamily project developers to allocate 15 percent of their units to moderate- and lowincoine housing. ${ }^{217}$ If land costs exceed HUD-FHA allowable maximums, the developer is nonetheless required to apply for subsidy housing, and must make up the land cost differential as best he can. In return, the

ASSEMBLY BILL NO. 2946

An act to add Section 65008 to the Government Code, relating to the Planning and Zoning Law.

Section 1. Section 65008 is added to the Government Code, to read:

Section 1. Section 65008 is added to the Government Code, to read:

65008. Any action pursuant to the provisions of this title by any city or county in this state which denies to any individual or gronp of individuals the enjoyment of residence, land ownership, tenancy or any other land use in this state because of racial, religious, or ethnic reasons is null and void. This section shall apply to a chartered city.

No city or county shall, in the enactment or administration of ordinances pursuant to this title prohibit or discriminate against, because of the method of fimancing or the intended occupancy, any development or project.

Nor shall any city or county treat federally subsidized, assisted, or insured housing in any inanner differently from conventional housing except pursuant to an affirnative plan to encourage such housing, which plan has been approved by the Director of HUD.

212. MASS. Gen. LAwS ANN. ch. 40B, \$§ 20-23 (Supp. 1971).

213. Similar legislation has been introduced in Wisconsm, Connecticut, and California. See D.M. Trubek, Will State Courts and Legislatures Eliminate Exclnsionary Land Use Controls?, June 15, 1971, at 37-43 (testimony before the U.S. Comm'n on Civil Rights, ou file with the author); A.B. 2953, Cal. Reg. Sess. (1971) (introduced by Assemblywoman Brathwaite).

214. Miami Valley Regional Planning Commission, A Housing Plan for the Miami Valley Region July 1970; Herbers, Suburbs Accept Poor in Ohio Housing Plan, N.Y. Times, Dec. 21, 1970, at 1, col. 3.

215. San Bernardino and Orange Counties in southern California are both considering the adoption of housing allocation plans. Report on Contract H-1260 for the month of July 1971, to Harold B. Finger, Assistant Secretary, U.S. Dep't of Housinig \& Urban Dev., on file with the author.

216. Crow v. Brown, Civil No. 14954 (D. Ga., filed Sept. 7, 1971).

217. Application No. F-425 for Amendment to Zoning Ordinance Text (Sept. 23, 1969), on file with the author. Fairfax County, Virginia, has adopted an ordmance requiring fixed percentages of low- and moderate-income housing in certain specified zones. FaIRFAX COUNTY, VA., CODE ch. 30 (1961); W.N. Curry, Fairfax Votes Low-Income Home Quotas, Washington Post, July 1, 1971, § B, at 1, col. 7. 
ordinance provides a density bonus froin which the developer might be able to realize some recoupment. Suit has been filed by builders who claim, inter alia, that the state zoning enabling act fails to authorize this sort of social engineering. ${ }^{218}$ However, county officials contend that $a b-$ sent some such arrangement, moderate- and low-income housing will not be constructed where it is badly needed. If the ordinance can induce the building of moderately priced housing closer to new centers of commerce and industry, thus alleviating property tax inequities and traffic congestion, a Fairfax-type ordinance may stand against the developers' challenge as serving legitimate land use objectives.

The question of how far localities inay go in turning their power to zone toward the achievement of broad social objectives has not been answered in most states. But the Supreme Judicial Court of Massachusetts, apparently eager to accommodate the law to the production of lowincome housing, seeins quite prepared to overlook the inconsistency of some municipal ordinances with the state zoning enabling act.

In Cameron. v. Zoning Agent of Bellingham, ${ }^{219}$ it legitimized an ordinance that permitted public housing to be located anywhere in town but in an industrial zone. In contrast, other multifamily structures were barred fron the agricultural districts where a private firm, the Varrasso Brothers, had contracted to build a 64-unit project for the elderly on local housing authority premises. Public housing was also exempted froin minimum intensity-of-use requirements (lot areas, coverage, and yard requirements).

Cameron contended that the Massachusetts zoning enabling act, prescribing that all zoning regulations "be uniform for each class of kind of building," was violated. If land use controls have been instituted to enable communities to prevent the externalities that a random mix of incompatible uses might generate, no reason is shown why public housing would disrupt an agricultural zone less than a privately developed apartment house. The court, in as clear a bit of casuistry as courts ever use, responded that the Bellingham ordinances treated all public housing alike and therefore the uniformity provisions were satisfied. On such a rationale, the other towns in Massachusetts would be perfectly free to bar public housing from their regular nultifamily zones as well as froin all other use districts and require that all such housing be constructed only after receiving a special permit. It supports the view that land use controls are just a means of enabling localities to ration land according to some ill-defined measure of "public interest." This approach would likely endanger more low-incoine housing than it would facilitate.

218. Savage-Focarty Companies v. Board of County Supervisors, Motion for Declaratory Judgment, filed in Circuit Court of Fairfax County, September 3, 1971.

219. — Mass.—, 260 N.E.2d 143 (1970). 
Would public lousing advocates be in a better position were Bellinglam to treat all multifamily apartments as special or conditional uses? Union City was doing something like that by rezoning agricultural land for apartments only on request. If present, unequal treatment could lave been shown nonetheless by scrutinizing the city's past practices.

The apparent advantage of the Bellingham method is that land for public housing might be acquired at bargam (that is, agricultural or single family) rates, especially if there is underzoning for inultifamily use. But if that were the case, the exemption of public housing from a community practice that resulted in artificially high land prices for apartments is a sinall defense for an otherwise pernicious scheme.

Assume that ample land has been zoned for apartments. If public housing may be constructed anywhere in single family zones, and if there is anything to the notion that apartments are incoinpatible with houses, the town is providing a break for public housing at the expense of some single family residents. The conditional use or special permit has the advantage of prohibiting, or at least blending, incompatible uses if proposed.

Since federal housing funds are in short supply, soine communities may bestow special treatinent on federally assisted housing with little fear of actually attracting many units. Their hope may be to shield exclusionary zoning ordinances from scrutiny. Where local governinents effectively bar new houses costing less than $\$ 30,000$ through zoning moratoriums, unrealistic standards, and arbitrary code enforcement, those who could afford a $\$ 25,000$ house are forced to bid agamst families of lesser means for existing inexpensive homes. Such lousing shortages may create low vacancy rates, thereby raising prices. Put simply, the brunt of any exclusionary land usc pattern, even a pattern aimed at the solidly middle-income market, has the potential of falling most heavily, albeit subtly and indirectly, on the poor. A few dozen or even a few hundred units of public or 236 housing should not provide a screen for judicial review. The standards for determining the reasonableness of zoning laws should regard impacts in the entire residential market.

\section{IV}

\section{The Extension of the California Referendum to Other Housing Programs}

When article XXXIV was enacted in 1950, it was made applicable to "low rent public housing," the only form of federally subsidized housing then available. Subsequently, other forms of assistance and even of public housing have evolved. The earliest variant of public housing used widely in California was the leasing program. Largely 
through the work of Congressman William B. Widnall of New Jersey, the United States Housing Act was amended in 1965 to allow the leasing of apartments in existing buildings. ${ }^{220}$ Real estate imterests, which had traditionally opposed public housing as a threat to free enterprise, welcomed the Widnall leasing program; ${ }^{221}$ properly utilized, it would fill vacancies in lean years.

Despite the deference to local sensibilities expressed in the requirement that each locality expressly approve the use of leasing funds, ${ }^{222}$ the question arose whether a public referendum was necescary before a housing authority could lease units in privately owned apartments. The California Attorney General, in 1966, ruled that the leasing program was not meant to be included. His opinion was based mostly on the official ballot argument that had accompanied the adoption of article XXXIV:

Time after time within the past year California communities have had public housing projects forced upon them without regard either to the wishes of the citizens or community needs. This is particularly a crucial matter in view of the fact that the long-term, multimillion dollar public housing contracts call for tax waivers and other forms of local assistance, which the Federal Government says will amount to HALF the cost of the federal subsidy on the project as long as it exists. ${ }^{223}$

The leasing program came into being as a response to the perfectly sensible notion that when there are ample vacancies in the housing market, available units ought to be utilized for the poor. A housing authority, when contracting to lease units, can insist that the entire building be made habitable and maintamed properly throughout the lease term, assuming that the landlord needs the lease badly enough. This attempt at upgrading only works well, however, when there are ample vacancies. In a tight housing market, leasing provides too little incentive for inuproving the existing stock. And leasmg on short terms often fails to encourage rapid new construction. Effective demand is generated, but this only enables the poor to bid against the near poor for the supply "as is." This shortcoming has been alleviated by a blending of section 23 with another innovation in the public housing program known as "turnkey." This is how the turnkey leasing program, described in part III, was derived. Under that construc-

220. United States Housing Act of $1937 \S 23$, as amended, Housing and Urban Development Act of 1965 \& 103 (a), 42 U.S.C. $\$ 1421$ (b) (1970).

221. See Note, Government Housing Assistance to the Poor, 76 Y ALE L.J. 508, 512-13 (1967). For a general discussion of the new attitudes of the National Association of Hoine Builders toward federally subsidized low- and moderate-income housing programs, see Lilley, supra note 206.

222. Umited States Housing Act of 1937 \& 23(a) (2), 42 U.S.C. $\$ 1421$ (b) (1970).

223. 47 Op. CAL. AtT'y GEN. 17 (1966). 
tion plan, private developers are invited to submit proposals for public lousing; the local housing authority then agrees to purchase a coinpleted project from the builder at a fixed price. This "turnkey" procedure is not practicable in California since, at the point the housing authority contracts to acquire legal title to the structure, the venture becomes subject to a commercially unacceptable condition: electorate approval. So, instead of contracting to buy the completed project, California housing authorities contract to lease the units under the section 23 leasing program for terms now as long as 20 years. Under a variant of turnkey leasing instituted to encourage hoineownership, single-family residences are privately constructed, leased to housing authorities under section 23, and subleased to individuals with options to purchase.

Though thousands of units have been constructed in California under the turnkey leasing program-and all without the benefit of referendums-that there has been no official attorney general's opinion or court ruling that these projects are exempted from the stricture of article XXXIV. HUD, private turnkey builders, and local housing authorities are relying principally on the 1966 Opinion of the California Attorney General concerning the straight leasing program. ${ }^{224}$

224. Two opinions have come close, however. In one, the attorney general was asked whether the referendum would apply if all the units in an FHA-insured apartment house were leased to persons eligible for public housing under lease-purchase agreements. The housing authority would simultaneously contract under section 23 to pay that portion of the market rent that tenants could not afford. The attorney general, in concluding that such an arrangement would be exempt from the anticle XXXIV requirement, relied on the fact that under this plan the housing authority would do no "developing, constructing, or acquiring." These were to be built privately.

The opinion simply ignored the "project" aspect of the development. Under the straight leasing prograin only a small percentage of units $\mathrm{m}$ an existing structure would be occupied by public housing eligibles, whereas under this plan the entire building might be occupied by aid recipients.

If the opinion had stopped at this point, turnkey-leasing units would certainly seem to be sheltered by it. However, special emphasis was given to the purchase-option aspect of this arrangement. Noting that article XXXIV applied to "low rent housing projects," the opinion underlined the words "low rent" and concluded with the observation that since this plan contemplated eventual ownership of the units by tenants, the units would in time cease to be a "low rental resource." In the ordinary turnkey-leasing arrangement, the purchase option runs in favor of the housing authority, not the tenants. If exercised, it would place the building in tax-exempt hands. Thus, at the point of exercise, a referendum might be required.

The opinion did point out that the project would be fully taxed since all programs funded under section 23 are expressly exempted from the tax-exemption provisions applicable to conventional public housing. 51 Op. CaL. ATT'y GEN, 42 (1968).

A second opinion along much the same limes held that a privately developed project would be exempt from article XXXIV if leased to a housing authority that, in turn, subleased units to public housing eligibles on rent-purchase contracts. Here the housing authority was the tenant under a master lease whereas in the above plan the individual aid recipients were tenants, with the housing authority contracting to provide a portion of the rent money. 
Whether the exemption of the leasing program from article XXXIV would cover turnkey leasing is thus open to question. At possibly the most crucial point, the programs are alike; since turnkeyleased units are privately owned during the lease term, they, too, are subject to a full measure of property tax. On the other hand, when the attorney general rendered his leasing opinion, no more than 10 percent of the units in any single structure were ordinarily usable for low-rent housing under the leasing program ${ }^{225}$ and the program contemplated only short-term leases. ${ }^{226}$ Under the turnkey leasing arrangenient, leases are of the entire building and nuust be long enough to enable private lenders to amortize a mortgage loan, so that at the end of the lease, the land and structure will support a loan at permissible and sensible loan-to-value ratios. There was a third feature of the leasing program that the attorney general thought significant in justifying its exemption fron article XXXIV, and it is difficult to say which way it cuts with respect to turnkey leasing: the article was aimed at "projects." Leasing entailed "no change in the physical quality of the comnunity," since units were leased in existing buildings. Most turnkeyleased buildings are of modest size, rarely larger and often smaller than apartment buildings in the neighborhood.227 Thus, the massive housing project aspect has been avoided, but these units constitute, arguably, niore than leased ones, a "development" within the hteral language of article XXXIV.

While it would thus be possible to distinguish turnkey leasing froin leasing in order to apply article XXXIV, such a result might well be unconstitutional. The Valtierra decision appears to have been based on the fact that public housing is tax-exempt. ${ }^{228}$ Remove this portion of the fiscal justification for the referendun and all that remains is a bare assertion that poor people are a drain on community resources,

Again, reliance was placed partly on the aspect of the plan that "contemplated eventual ownership by the low income family, thus taking the plan without the operation of the article." The opinion also emphasized, however, the two features that these plans share with turnkey-leasing: private development and full property tax exposure. 52 Op. Cal. ATT'y Gen. 133 (1969).

225. An exception is provided "to the extent that the agency . . . determines such limit should not be applied." United States Housing Act of $1937 \S 23(c), 42$ U.S.C. $\S 1421(b)(1970)$.

226. Twelve to 60 months. See Conference Report to Accompany H.R. 7984, H.R. REP. No. 365, 89th Cong., 1st Sess. (1965); 2 U.S. CoDe Cong. \& AD. News 2625 (1965).

227. For the second quarter of fiscal year 1971, the average number of dwelling units per turnkey project for which annual contribution contracts were executed was 99.18, that, is 73 projects with 7,289 units. For the same period, the average number of dwelling units per turnkey projects in HUD Region IX (California, Nevada, Arizona, and Hawaii) for which annual contribution contracts were executed was 67.2. Data prepared by FHA Division of Research and Statistics, U.S. Dep't of Housing and Urban Development, Housing Production and Mortgage Credit, Table 2, Feb. 12, 1971.

228. See text accompanying note 120 supra. 
not a particularly compelling justification for putting matters to the electorate. If the referendum were interpreted as covering a larger share of all new housing for poor people, the form and extent of the potential deprivation should merit closer judicial scrutiny. Thus it would not be surprising if the leasing exemption were officially extended to turnkey leasing. But the extension has yet to receive any such sanction.

Congress could, of course, exempt federally assisted housing from all state and local requirements. The reason that the supremacy clause argument failed in Valtierra-and it failed even with the three-judge court that was favorably disposed toward the equal protection claimwas simply that, as the Supreine Court put it, "federal legislation does not purport to require that local governments accept [aid to state and local governments for the creation of low-rent public housing] or to outlaw referendums on whether the aid should be accepted."220

However, there are cases that find congressional intent to preempt one area of state law in favor of the turnkey program. Congress has indicated its willingness to provide local governments with a choice of construction methods, and the only way that a local authority can experiment with privately built units is under the turnkey program. Because the proper deployment of turnkey units precludes open bidding, a number of state courts have held open-bidding statutes inapplicable on supremacy clause grounds. ${ }^{230}$ But inferring preeinption from bidding requirements is a far less heroic imputation of congressional intent than that required to strike down a referendum requirement.

The argument for an inferred preemption of the referendum on rentsupplement ${ }^{231}$ housing is but a little stronger. In the enactment of the rent supplement program, Congress debated whether to require local ap-

229. 402 U.S. at 140.

230. Lehigh Constr. Co. v. Housing Authority, 56 N.J. 447, 267 A.2d 41 (1970); Commissoner of Labor and Indus. v. Lawrence Housing Authority, - Mass. -, 261 N.E.2d 331 (1970).

231. Rent supplement payments are authorized by the Housing and Urban Development Act of 1965 \& 101, 12 U.S.C. \& 1701s (1970). These payments bridge the gap between $25 \%$ of a family's income and the "fair market rental" for the dwelling unit. Rent supplement payments range from a minimum of $10 \%$ of a unit's market rent to a maximum rent supplement payment equal to $70 \%$ of a unit's market rent. After a nonprofit, limited dividend, or cooperative sponsor obtains a commitment to receive rent supplement payments for a period of up to 40 years, he then builds a project financed under an appropriate FHA low-income housing mortgage assistance program. Presently, the major vehicle for rent supplement units, the section 236 program, has a statutory lumit of $40 \%$ on the number of units in a section 236 project that can be occupied by tenants receiving rent supplement assistance. Housing and Urban Development Act of $1969 \S 112,12$ U.S.C. $\$ 1701$ s (1970). HUD, by regulation, has prescribed a limit of $20 \%$ on the number of units in a section 236 project which can be occupied by tenants receiving rent supplement assistance. RHA Circular of Feb. 12, 1969. For a detailed 
proval. ${ }^{232}$ A compromise resulted: rent supplement funds are available to any community with a workable program (which it must have to be eligible for urban renewal funds and certain other federal funds) or, absent a workable program, to any community that resolves to accept the program. ${ }^{233}$ Whether a city council is free to delegate this authority or to seek the advice of the electorate on the requisite rent supplement resolution is not an issue explicitly dealt with in the federal statutes. Therefore, the matter may have to be resolved under state law. Generally a city council is free to seek advice from the public on such issues, which require only one resolution at the outset and are therefore classified as legislative, not administrative, decisions. ${ }^{234}$ Some communities, however, have enacted their rent supplement resolutions on a conditional basis, reserving the right to approve individual project applications as they are made to HUD. ${ }^{235}$ Such project decisions are usually deemed administrative under state law and hence only delegable with state legislative authorization. ${ }^{236}$

Finally, there is the subsidy program, section 236 . While public-housing and rent-supplement monies are given only to communities

description of the Rent Supplement Program, see National InstituTE for Education IN LAW AND Poverty, HaNdBook on Housing Law, ch. V, pt. III, at 40-85. See also Note, Government Housing Assistance to the Poor, 76 Yale L.J. 508, 518-27 (1967).

232. The tensions generated by rent supplement debate surface clearly in the Minority Views in H.R. Rep. No. 265, 89th Cong., 1st Sess., 2 U.S. Code CoNG. \& AD. News 2681, 2683-84 (1965) (concerning "economic" integration). Compare CoNF. Rep. No. 679, 89th Cong., 1st Sess. (1965), 2 U.S. Code Cong. \& Ad. News 2696 (1965).

233. This compromise does not appear in the rent supplement legislation, but it does appear in FHA regulations and in legislation appropriating funds for the rent supplement program. See 24 C.F.R. \& 5.15(c) (1971); Second Supp. Appropriation Act, 1966, approved May 13, 1966, Pub. L. No. 89-426, 80 Stat. 141, 143; Independent Offices Appropriations Act, 1967, approved Sept. 6, 1966, Pub. L. No. 89-555, 80 Stat. 663; Independent Office and Department of Housing and Urban Development Appropriation Act, 1968, approved Nov. 3, 1967, Pub. L. 90-121, 81 Stat. 341, 356.

234. See, e.g., Housing Authority v. Superior Court, 35 Cal. 2d 550, 557-558, 219 P.2d 457, 460-61 (1950).

235. One example is a resolution adopted by the City Council of the City of Santa Ana, California, Feb. 16, 1970, which approved rent supplement, but only for two specific projects. The resolution was rescinded Apr. 6, 1970.

236. See Saks \& Co. v. City of Beverly Hills, 107 Cal. App. 2d 260, 237 P.2d 32 (2d Dist. 1951); Cady v. City of Detroit, 289 Mich. 499, 286 N.W. 805 (1939).

Even with express state authorization there are constitutional limits to the kinds of zoning decisions that can be delegated to the people. Zoning determinations must rest on sufficiently predictable and ascertamable criteria. State v. Gottfried, 163 Ohio St. 469, 127 N.E.2d 371 (1955); Cassell v. Lexington Township Bd. of Zoning Appeals, 163 Ohio St. 340, 127 N.E.2d 11 (1955). Consistent with this requirement of sufficiently clear zoning criteria are decisions voiding zoning schemes that make certain zoning determinations contingent on approval of a certam percent of the neighborhood landowners. The Supreme Court in Gorieb v. Fox, 274 U.S. 603 (1926), upheld an ordinance fixing a building line while voiding a similar building line ordmance in Eubank. The Go- 
that have expressed a need and willingness to have them, 236 has no such requirement. It is a program that was endorsed and supported by homebuilders during the high-interest-rate, depressed-housing-market years of 1969 and $1970 ; 237$ their slogan for section 235 of the National Housing Act, the parallel program for single-family houses, was "Stay alive with 235." Builders were familiar with the FHA mortgage msurance and with the need to underwrite interest rates in order to keep a tolerable demand level as rates approached 9 per cent. The 235 and 236 programs were intentionally designed as ordinary inortgage insurance programs that happen to have interest subsidy contracts appended. To have given local communities the option of excluding these units would have jeopardized production levels. Builders did not want this program subjected to the whims of local councils any more than they wanted Congress to require local sanction for FHA mortgage insurance or VA guarantees. Extending a referendum requirement to this form of subsidy, therefore, would raise a difficult supremacy clause issue that the National Association of Home Builders, among others, would have good cause to litigate forcefully.

There is a possibility that it may be litigated even if no state extends a referendum requirement to these programs. Under new procedures authorized by the Office of Management and Budget and distributed in a circular known as A-95, ${ }^{238}$ certam regional planning authorities are allowed to review applications for all major public funding in their areas. The scope of review is to be no greater than that required under several existing federal laws, none of which even come close to sanctioning the exclusion of 235 or 236 housing simply because a community does not want it. Some communities may pressure planning agencies to issue negative A-95 reports in an attempt to halt unwanted 236 projects. If that occurs, the scene may be set for a challenge of local prerogatives.

\section{CONCLUSION}

Valtierra was widely received as an invitation for citizens to block unwanted housing developments. As with most popular interpretations

rieb Court explained its action in terms of the citizen involvement in Eubank:

The [Eubank] ordinance . . . . required the committee on streets to fix a building line upon the request of the owners of two-thirds of the property abutting on any street. The ordinance was held bad by this court because it left no discretion in the committee.

274 U.S. at 610 (emphasis in original).

237. See Lilley, supra note 206 , at $439-40$.

238. United States Budget Bureau Circular A-95, July 24, 1969, issued pursuant to the Intergovernmental Cooperation Act of $1968 \$ \S 401(\mathrm{a}), 403,42$ U.S.C. $\$ \S 4231$ (a), 4233 (1970), and Denonstration Cities and Metropolitan Development Act of $1966 \S 204(a), 42$ U.S.C. \$ 3334(a) (1970). 
of court opinions, the public view was not as far wrong as legal technicians might have expected. Journalists may err by trying to make the complex deceptively simple; law review authors-this one anywaybalance the scales by making the simple woefully complex.

A few questions remain bearing directly on the course of public housing referendums. Whether other states are free to enact referendum requirements similar to California's depends on how important the use of the referendum already is in those states. Absent a history of referendums as an integral part of state and local practice, especially if the establishment of a public housing referendum is accompanied by racial and class slurs, a new referendum requirement will probably not be sustained.

An effort to expand the coverage of the existing referendum requirement to encompass other forms of lousing subsidy such as the rent supplement or 236 progranis, which are subject to property tax, would be even less likely to succeed since the Court's approval of article XXXIV hinged largely on the exemption of public liousing from local taxation. Projects constructed under the turnkey leasing program are fully taxed and provide a major share of low-rent public housing in California; hence, they are also probably exempt from article XXXIV.

If a locality manipulates its land use controls so as to bar blacks or other minorities, and particularly if this goal is accomplished in an obvious way and in a context of past discriminatory official decisions, the Court can be expected to overturn the locality's land use determinations. Valtierra and a few other cases suggest, however, a greater concern to distinguisl 1 laws that are easily dubbed racist from those with no more to condemn them than that they happen at times to affect racial minorities disproportionately. Moreover, Valtierra affirms once again that poverty or wealth classifications are not being assigned that same station as racial categories. This means that zoning laws, which usually lave their impact on a class or economic and not on an explicitly racial basis, must be approached at a different level.

The worst abuses in zoning would be easier to reach with a more precise measure than is used in the "suspect classification" test. Unless the courts are to reject most local land use controls, indicia are needed to distinguish important from less important abuses of the zoning power. A number of state court cases point to the factors in a zoming sclieme that most justify an exacting judicial examination.

These elements liave been labelled here as form, uniqueness, kind, and extent. They are indicia more reminiscent of due process infringements than of equal protection violations. Although the Court has shown a renewed willingness to utilize a due process framework, as in 
Boddie, at this level of generality no persuasive prediction can be made that the Supreme Court will resolve the major exclusionary zoning challenges the way that courts have, for example, in Virginia, Pennsylvania, Ohio, or Illinois. The Court's refusal to follow an equal protection path only leaves more tantalizing the possibility of its choosing a due process approach for reaching many of the same ends. Since such an approach would be more expedient for confronting local abuses of land use control authority, Valtierra can be seen as marking the end of a doctrinal detour. On the other hand, it may be seen as one among a set of recent civil rights cases that are parallel to those that brought to a standstill any meaningful review of state socio-economic legislation in the late 1930 's and early 1940 's. ${ }^{230}$ If so, the doctrinal move away from the rigidity of suspect classification and fundamental interest analysis may lead to a contrary rigidity. Or, as has been suggested here, these cases may point the way to a better path - the utilization of a "reasonableness" test in an increasing number of fields, with the scrutiny for reasonableness calibrated to the demands of the situation.

239. For a discussion of the Court's abrupt, unexplained abandonment of economic due process review, see McCloskey, Economic Due Process and the Supreme Court, 1962 Sur. CT. Rev. 34. Professor McCloskey argued persuasively that there are no principled bases for distinguishing economic from civil rights. He concluded, however, that for reasons of expediency, the Court might have been wise to desist from protecting economic rights. The expedients involved the "practical, political limitations on the range of Court power" and the drains on the time and talents of the Court in working out the problems of the civil rights tasks the Court had assumed. Professor McCloskey wrote this paper nearly ten years ago. The Court now seems close to identifying the implications and choosing among alternatives opened by the civil rights cases. This would be especially true if the Burger Court continues drawing boundaries around the scope of protected rights. Also, the political security of the Court's position may be buffered by its new members, who may liave appeal to the very constituency that was most critical of the Warren Court. 